Pacific Northwest

National Laboratory

Operated by Battelle for the

U.S. Department of Energy

\section{Waste Form Release Calculations for the 2005 Integrated Disposal Facility Performance Assessment}

D. H. Bacon

B. P. McGrail

July 2005

Prepared for the U.S. Department of Energy under Contract DE-AC05-76RL01830 


\title{
DISCLAIMER
}

This report was prepared as an account of work sponsored by an agency of the United States Government. Neither the United States Government nor any agency thereof, nor Battelle Memorial Institute, nor any of their employees, makes any warranty, express or implied, or assumes any legal liability or responsibility for the accuracy, completeness, or usefulness of any information, apparatus, product, or process disclosed, or represents that its use would not infringe privately owned rights. Reference herein to any specific commercial product, process, or service by trade name, trademark, manufacturer, or otherwise does not necessarily constitute or imply its endorsement, recommendation, or favoring by the United States Government or any agency thereof, or Battelle Memorial Institute. The views and opinions of authors expressed herein do not necessarily state or reflect those of the United States Government or any agency thereof.

\author{
PACIFIC NORTHWEST NATIONAL LABORATORY \\ operated by \\ BATTELLE \\ for the \\ UNITED STATES DEPARTMENT OF ENERGY \\ under Contract DE-AC05-76RL01830 \\ Printed in the United States of America \\ Available to DOE and DOE contractors from the \\ Office of Scientific and Technical Information, \\ P.O. Box 62, Oak Ridge, TN 37831-0062; \\ ph: (865) 576-8401 \\ fax: (865) 576-5728 \\ email: reports@adonis.osti.gov
}

\author{
Available to the public from the National Technical Information Service, \\ U.S. Department of Commerce, 5285 Port Royal Rd., Springfield, VA 22161 \\ ph: (800) 553-6847 \\ fax: (703) 605-6900 \\ email: orders@ntis.fedworld.gov \\ online ordering: http://www.ntis.gov/ordering.htm
}




\section{Waste Form Release Calculations for the 2005 Integrated Disposal Facility Performance Assessment}

D. H. Bacon

B. P. McGrail

July 2005

Prepared for

the U.S. Department of Energy

under Contract DE-AC05-76RL01830

Pacific Northwest National Laboratory

Richland, Washington 99352 


\section{Summary}

A set of reactive chemical transport calculations was performed with the Subsurface Transport Over Reactive Multiphases (STORM) code to evaluate the long-term performance of a representative lowactivity waste glass in a shallow subsurface disposal system located on the Hanford Site. Twodimensional simulations were run until the waste form release rates reached a quasi-stationary-state, usually after 2,000 to 4,000 yr. The base case for this analysis was four vertically stacked LAWA44 glass waste packages under a recharge rate of $0.9 \mathrm{~mm} \mathrm{yr}^{-1}$. The maximum normalized technetium release rate from LAWA44 glass under a constant recharge rate of $0.9 \mathrm{~mm} \mathrm{yr}^{-1}$ was $0.09 \mathrm{Myr}^{-1}$. The unit $\mathrm{Myr}^{-1}$ stands for "per million years," indicating the rate at which the technetium, normalized by the amount originally in the four waste packages, would be released per million years. The primary difference between the waste form release simulations for the 2001 Immobilized Low Activity Waste Performance Assessment (ILAW PA) and the simulations described in this document is the number of materials considered. Whereas the ILAW PA considered only LAWABP1 glass, the current IDF PA also describes radionuclide release from three Waste Treatment Plant (WTP) glasses (LAWA44, LAWB45 and LAWC22), two bulk vitrification glasses (six-tank composite and S-109), and three grout waste forms (containing AgI, $\mathrm{BaI}_{2}$, and $\left.\mathrm{Ba}\left(\mathrm{IO}_{3}\right)_{2}\right)$. All WTP and bulk vitrification glasses perform similarly. However, the Tc-99 release from the salt in the cast refractory surrounding the bulk vitrification waste packages is 2 to 170 times higher than the glass release rate and dependent on the water recharge rate. Iodine-129 release from grouted waste forms is highly sensitive to the solubility of the iodine compound contained in the grout. The normalized iodine release rate from grout containing barium iodate is $9.1 \times 10^{-1} \mathrm{Myr}^{-1}$. 



\section{Contents}

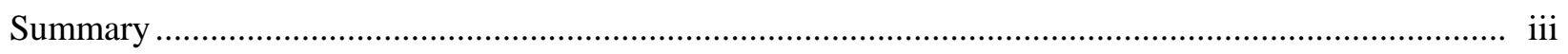

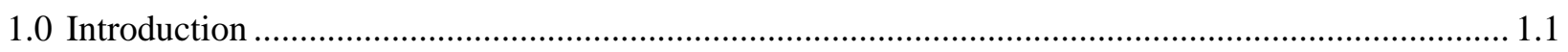

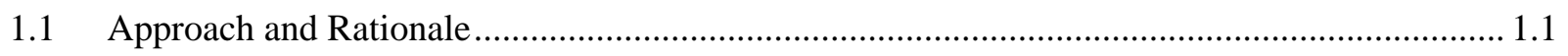

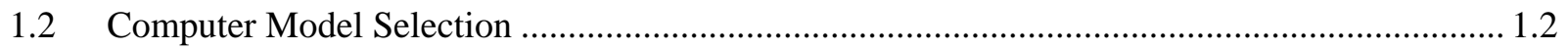

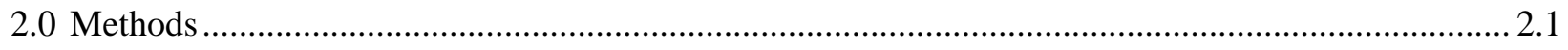

$2.1 \quad$ Model Setup and Parameterization .................................................................................. 2.1

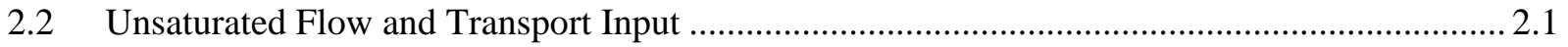

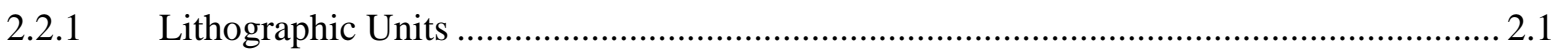

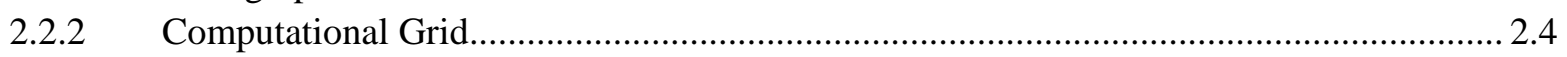

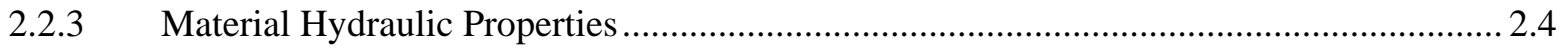

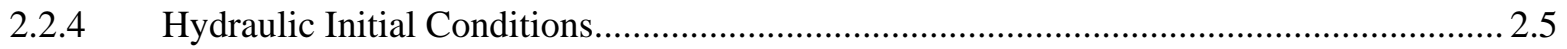

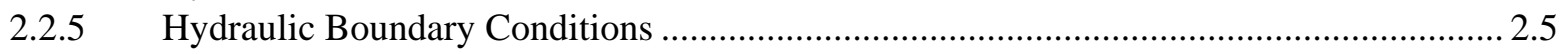

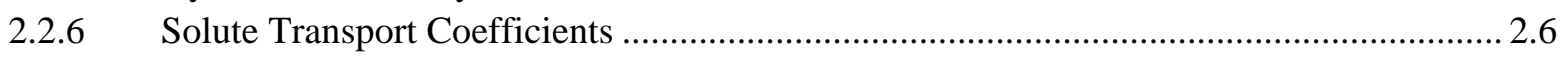

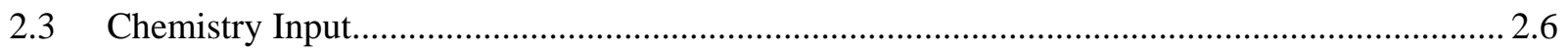

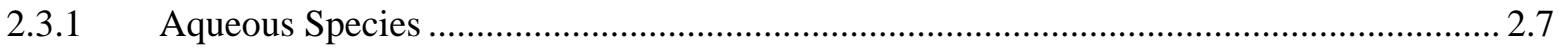

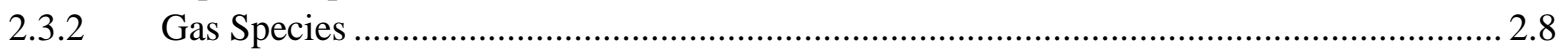

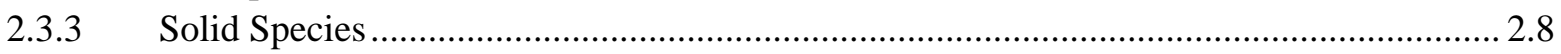

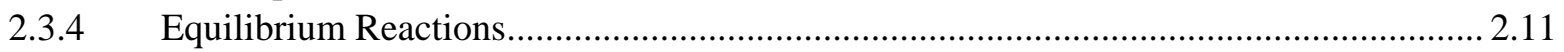

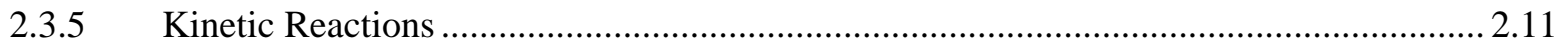

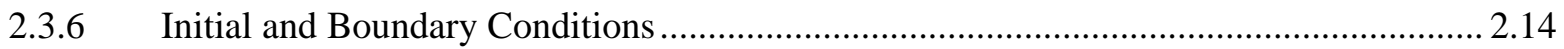

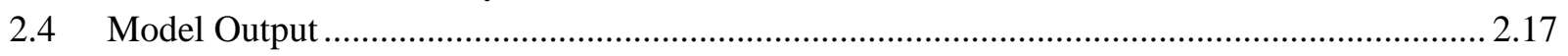

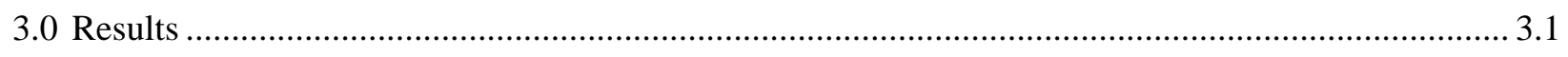

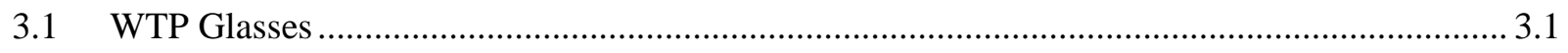

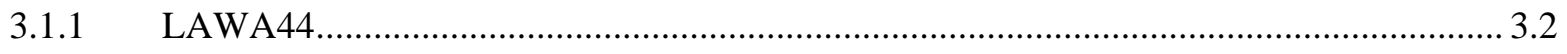

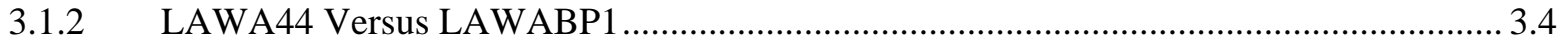

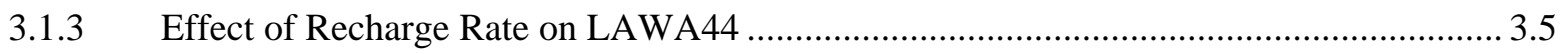

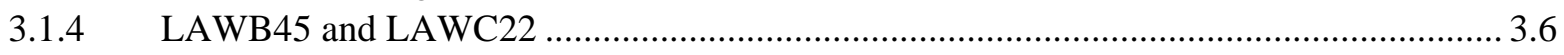

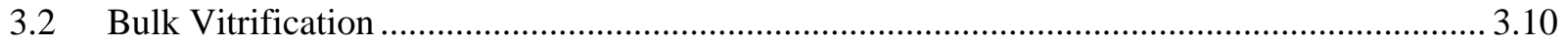

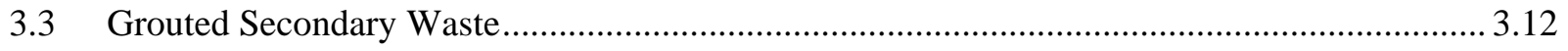

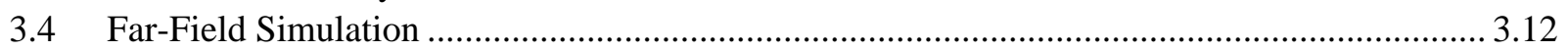

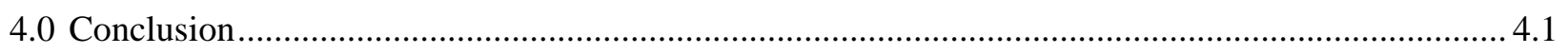

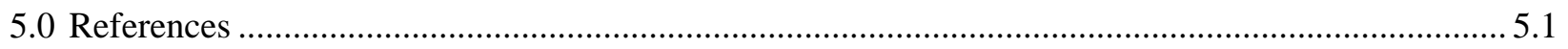




\section{Figures}

1 Lithographic Units for WTP Glass Waste Form Release Simulations...........................................2.2

2 Lithographic Units for Bulk Vitrification Waste Form Release Simulations...................................2.2

3 Lithographic Units for Grouted Secondary Waste Form Release Simulations ................................ 2.3

4 Technetium flux to Vadose Zone, Normalized by Total Amount of Technetium Originally in WTP Glass Waste Packages at Recharge Rate of $0.9 \mathrm{~mm} \mathrm{yr}^{-1}$

5 Steady-State Moisture Content for $0.9 \mathrm{~mm} \mathrm{yr}^{-1}$ Recharge Rate WTP Glass

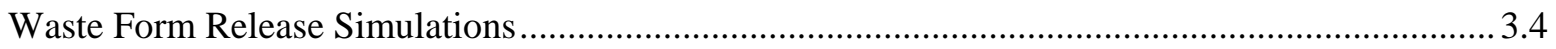

6 Maximum pH for LAWA44 Waste Form Release Simulations at $0.9 \mathrm{~mm} \mathrm{yr}^{-1}$ Recharge Rate ......... 3.4

7 Maximum Glass dissolution rate for LAWA44 Waste Form Release Simulations at $0.9 \mathrm{~mm}$ yr-1 Recharge Rate.

8 Maximum Normalized Technetium Concentrations for LAWA44 Waste Form Release Simulations at a $0.9 \mathrm{~mm}$ yr-1 Recharge Rate.

9 Technetium Flux to the Vadose Zone Normalized by Total Amount of Technetium Originally in WTP Glass Waste Packages for LAWA44 and LAWABP1 Glasses Using Rate Law Parameters from 2001 PA and 2005 Data Package

10 Technetium Flux to the Vadose Zone Normalized by Total Amount of Technetium Originally in WTP Glass Waste Packages at Various Recharge Rates

11 Technetium Flux to the Vadose Zone at a Recharge Rate of $0.9 \mathrm{~mm} \mathrm{yr}^{-1}$ for Various WTP Glasses.

12 Maximum pH for LAWB45 Waste Form Release Simulations at $0.9 \mathrm{~mm} \mathrm{yr}^{-1}$ Recharge Rate ........ 3.7

13 Maximum pH for LAWC22 Waste Form Release Simulations at $0.9 \mathrm{~mm} \mathrm{yr}^{-1}$ Recharge Rate ........ 3.7

14 Technetium Flux to the Vadose Zone at Recharge Rate of $0.9 \mathrm{~mm} \mathrm{Yr}^{-1}$ for LAWA44 and LAWB45 Glasses Alone or Combined

15 Maximum pH for LAWA44 with LAWAB45 Waste Form Release Simulations at $0.9 \mathrm{~mm} \mathrm{yr}^{-1}$ Recharge Rate

16 Technetium Flux to the Vadose Zone at a Recharge Rate of $0.9 \mathrm{~mm} \mathrm{yr}^{-1}$ for LAWA44 and LAWC22 Glasses Alone or Combined.

17 Maximum $\mathrm{pH}$ for LAWA44 with LAWAC22 Waste Form Release Simulations at a $0.9 \mathrm{~mm} \mathrm{yr}^{-1}$ Recharge Rate .

18 Comparison of Technetium Flux to the Vadose Zone Normalized by Total Amount of Technetium Originally in Bulk Vitrification Waste Packages for Different Waste Glass Formulations at Recharge Rate of $0.9 \mathrm{~mm} \mathrm{yr}^{-1}$.....

19 Comparison of Technetium Flux to the Vadose Zone Normalized by Total Amount of Technetium Originally in Bulk Vitrification Waste Packages for Six-Tank Composite Glass at Various Recharge Rates

20 Comparison of Normalized Flux of Technetium Salt to the Vadose Zone for Different Water Recharge Rates

21 Iodine Flux to the Vadose Zone at a Recharge Rate of $0.9 \mathrm{~mm} \mathrm{yr}^{-1}$ for Various Iodine Salts in Grout Waste Forms 


\section{Tables}

1 Relative Volume of Solid Species in Material Zones ................................................................. 2.3

2 Specific Surface Area of Solid Species in Material Zones............................................................2.4

3 Material Hydraulic Properties Used in Simulations ...................................................................... 2.4

$4 \quad$ Key Aqueous Species Produced by the Dissolution of Waste Glass and Grout .............................. 2.7

5 Composition of Glasses Used in Simulations ........................................................................... 2.8

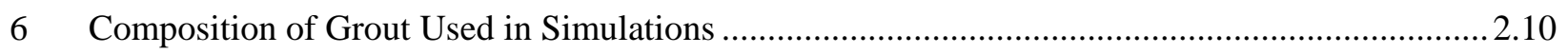

$7 \quad$ Composition of Native and Surrounding Materials Used in Simulations ....................................... 2.10

8 Composition of Secondary Minerals Used in Simulations.............................................................2.10

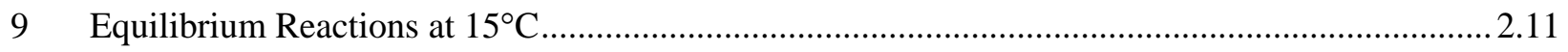

10 Summary of Kinetic Rate Parameters Used for Glasses .......................................................... 2.13

11 Kinetic and Equilibrium Geochemical Parameters for Mullite ................................................... 2.13

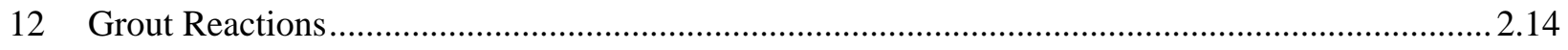

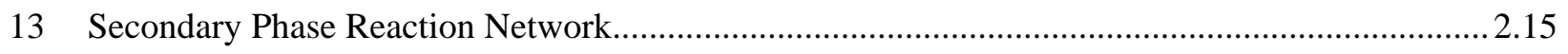

14 Initial Aqueous Concentrations Used in Simulations..................................................................2.15

15 Results of Waste Form Sensitivity Cases...................................................................................... 3.1

16 Maximum Normalized Technetium Flux to the Vadose Zone for Various Recharge Rates............. 3.6

17 Upper Boundary Aqueous Species Concentrations Used in Far-Field Simulation......................... 3.13 


\subsection{Introduction}

The Hanford Site in southeastern Washington State has been used extensively by the U.S. Department of Energy (DOE) to produce nuclear materials for the U. S. strategic defense arsenal. As a result, a large inventory of radioactive and mixed waste has accumulated in 177 buried single- and double-shell tanks. Liquid waste recovered from the tanks will be pretreated to separate the low-activity fraction from the high-level and transuranic wastes. The low-activity waste (LAW) will be immobilized in glass using vitrification and placed into a near-surface disposal system on the Hanford Site. The immobilized lowactivity waste (ILAW) at Hanford is among the largest volumes of waste within the DOE complex and is one of the largest inventories of long-lived radionuclides planned for disposal in a low-level waste facility (approximately 2.4 million curies total activity). Before the ILAW can be disposed, DOE must approve a performance assessment (PA), which is a document that describes the long-term impacts of the disposal facility on public health and environmental resources. A sound scientific basis for determining the longterm release rates of radionuclides from LAW glasses must be developed if the PA is to be accepted by regulatory agencies, stakeholders, and the public and be in accord with the Tri-Party Agreement. The Hanford Integrated Disposal Facility (IDF) Program is planning to issue a PA in July 2005. The major goals of the IDF PA activity are to:

- $\quad$ support the design of disposal facilities

- obtain approval to dispose of Hanford ILAW and other wastes in the tanks

- $\quad$ provide a technical basis for final closure of the disposal facilities.

\subsection{Approach and Rationale}

A critical component of the IDF PA will be providing quantitative estimates of radionuclide release rates from the engineered portion of the disposal facilities (source term). Computer models are essential for this purpose because effects on groundwater resources must be projected out 10,000 years and longer. Details on the recommended technical strategy for developing this source term have been published (McGrail et al. 2003) and have undergone review by an international panel of experts.

The 2001 ILAW PA (Mann et al. 2001) showed that a key variable was the waste form release rate, calculated over thousands of years. In that PA, the waste form release rate was evaluated by modeling the basic physical and chemical processes that are known to control the waste form dissolution behavior, instead of using empirical extrapolations from laboratory "leaching” experiments commonly used in other performance assessments. This methodology was adopted for the following reasons:

- The radionuclide release rate from dissolving silicate glass or grout cannot be determined independently of other system variables. For example, neglecting the waste form composition, the glass dissolution rate is a function of three variables: temperature, $\mathrm{pH}$, and composition of the fluid contacting the glass (McGrail et al. 2001). The temperature of the ILAW disposal system is assumed to be known and constant. However, both the $\mathrm{pH}$ and the composition of the fluid contacting the glass are variables affected by flow rate, reactions with other engineered materials, gas-water equilibria, secondary phase precipitation, alkali ion exchange, and glass dissolution, classic feedback mechanisms. Consequently, glass dissolution rates vary both in time and as a 
function of position in the disposal system. A "leach rate" or radionuclide release rate parameter that cannot be assigned to a waste form in such a dynamic system.

- One of the principal purposes of this IDF PA is to provide feedback to engineers regarding the effects of design options on disposal system performance. A model based on empirical release rates for different waste forms is inadequate for this task. Unfortunately, the robust methodology we used comes with additional requirements. First, detailed information is needed on the reaction mechanisms controlling the dissolution behavior of the waste form. Significantly more laboratory experiments are required to obtain the rate law parameters needed for the models used for our simulations. Second, the model now being used (described in the next section) is markedly more complex than a model based on empirical release rates because of its ability to simulate reactive transport coupled with heterogeneous, unsaturated flow. Execution times with today's most sophisticated massively parallel computers can be two weeks for the twodimensional (2-D) simulations presented in this report. The benefits, however, particularly with regard to the technical defensibility of the methodology and results, far outweigh the penalties.

\subsection{Computer Model Selection}

The code selection criteria and selection process used is documented in Selection of a Computer Code for Hanford Low-Level Waste Engineered-System Performance Assessment (McGrail and Bacon 1998). The needed capabilities were identified from an analysis of the important physical and chemical processes expected to affect LAW glass corrosion and the mobility of radionuclides. The available computer codes with suitable capabilities were ranked in terms of the feature sets implemented in the code that match a set of physical, chemical, numerical, and functional capabilities needed to assess release rates from the engineered system. The highest-ranked computer code was found to be the STORM code developed for DOE at Pacific Northwest National Laboratory (PNNL) to evaluate arid land disposal sites (Bacon et al. 2004).

STORM has the capability to simulate the special glass kinetic reaction in which many aqueous species are released, but equilibrium depends on only a few, such as silica and aluminum. Also, reactive transport in STORM is fully coupled with unsaturated flow; the unsaturated flow field may be altered by dissolution and precipitation of minerals. Since the 2001 ILAW PA, STORM has been modified to run efficiently on massively parallel supercomputers, shortening execution times 100 -fold and enabling the use of 2-D simulations for this IDF PA. This allows a more realistic simulation of water flow around the waste packages than in the 1-D simulations used in the ILAW PA. The verification studies for STORM are documented in the STORM user's guide (Bacon et al. 2004). 


\subsection{Methods}

\subsection{Model Setup and Parameterization}

This section details the data in the STORM code input data file (Bacon et al. 2004). Input data to STORM can be divided into 1) unsaturated flow and transport and 2) chemistry. Entries for unsaturated flow and transport include 1) lithographic units, 2) hydraulic properties, and 3) hydraulic initial and boundary conditions. STORM was used to compute the flow field in the near-field region based on hydraulic properties for the materials and specified initial and boundary conditions. Chemistry input to STORM consists of entries for aqueous, gas, and solid species; equilibrium reactions; kinetic reactions; and geochemical initial and boundary conditions. These are described below.

A variety of waste form materials have been simulated, including three Waste Treatment Plant (WTP) glasses (LAWA44, LAWB45, and LAWC22), grout, and two bulk vitrification glasses, six-tank composite and S-109. Data on these waste materials and near- and far-field materials were principally defined from facility design documents (Puigh 2004), the near-field hydraulic properties data package (Meyer et al. 2004), or the far-field hydraulic properties data package (Khaleel 2004). The properties of these materials are detailed below.

\subsection{Unsaturated Flow and Transport Input}

\subsubsection{Lithographic Units}

To establish a consistent framework for overlaying a computational grid on the spatial domain of interest, a set of material zones or lithographic units are defined for units with similar hydrogeological and geochemical properties. These zones are usually related to disposal design components, geologic formations, or geologic facies determined from borehole analyses. However, because there are practical limits to the resolution of the model grid, material zones may also include combinations of materials that are assigned uniform hydraulic and/or chemical properties. Classification of these materials into appropriate zones was performed as a part of the near-field hydraulics data package (Meyer et al. 2004).

The WTP glass simulations encompass a 2-D vertical stack of four waste packages near the center of a single trench (Figure 1). The WTP glass waste packages are $2.3 \mathrm{~m}$ tall, $1.22 \mathrm{~m}$ wide, and filled with glass to a height of $1.96 \mathrm{~m}$. The layers in the IDF trench were assumed to be $1 \mathrm{~m}$ apart vertically, while waste packages were spaced $30 \mathrm{~cm}$ apart horizontally. It is not likely that the waste packages will be perfectly aligned horizontally, so to more realistically simulate flow, the waste packages are offset horizontally $10 \mathrm{~cm}$ relative to the waste package above or below.

The bulk vitrification waste package simulation domain consists of four 2.44 x 2.44-m bulk vitrification waste packages stacked in a column and separated by $0.86 \mathrm{~m}$ in the vertical direction. The waste packages are surrounded by backfill soil that overlies Hanford sand (Figure 2). While the average waste package spacing was assumed to be $30 \mathrm{~cm}$, each waste package is offset $10 \mathrm{~cm}$ horizontally relative to the package above and below. The total height of the trench is $17.8 \mathrm{~m}$. The bottom of the 


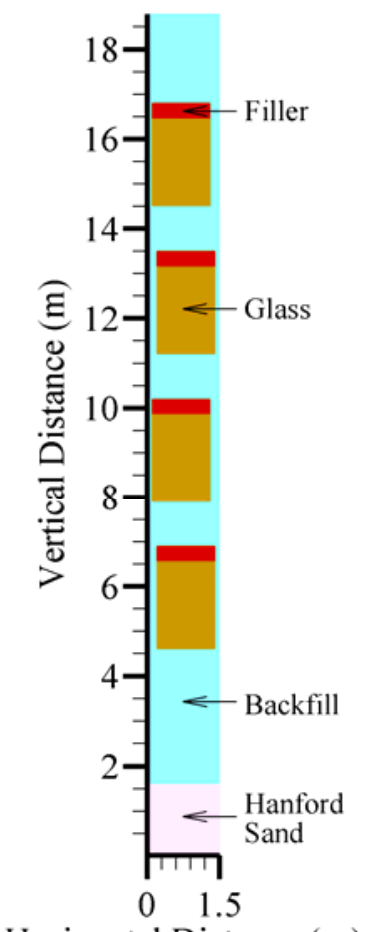

Horizontal Distance $(\mathrm{m})$

Figure 1. Lithographic Units for WTP Glass Waste Form Release Simulations

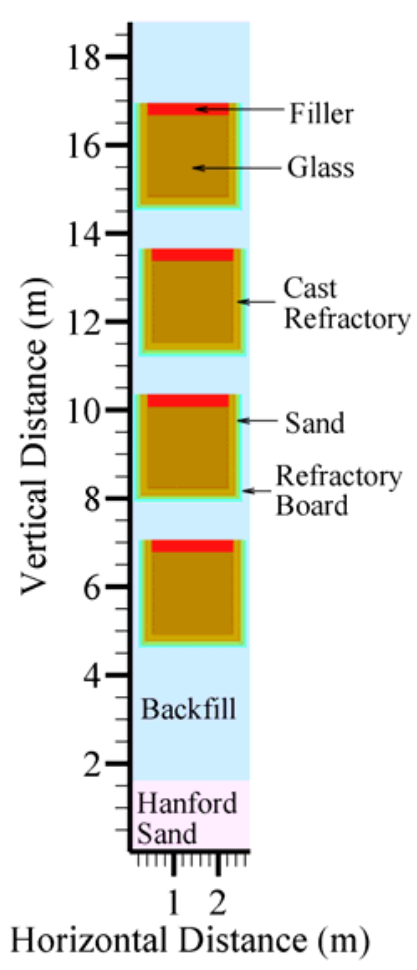

Figure 2. Lithographic Units for Bulk Vitrification Waste Form Release Simulations

lowest waste package is $4.6 \mathrm{~m}$ above the bottom of the model. The waste glass is surrounded by an insulating layer of cast refractory $16 \mathrm{~cm}$ thick, then a layer of insulating sand $8 \mathrm{~cm}$ thick, and finally a layer of refractory board $6 \mathrm{~cm}$ thick. The waste packages shown in Figure 1 are filled with glass to a height of $1.86 \mathrm{~m}$. The rest of the package is filler material with the same hydraulic properties as backfill.

The grouted secondary waste package domain is a 2-D vertical stack of four waste packages near the center of a single trench (Figure 3). The grouted secondary waste packages are $2.44 \mathrm{~m}$ tall, $1.22 \mathrm{~m}$ wide, and filled to the top with grout. The grout waste packages in the IDF trench were assumed to be $1 \mathrm{~m}$ apart vertically, $30 \mathrm{~cm}$ apart horizontally, and offset horizontally by $10 \mathrm{~cm}$ relative to adjacent packages.

For each lithographic unit, a list of the solid species that make up the unit is required. For each solid, the relative volume and the specific surface area are needed. Initial values for these variables for each lithographic unit are listed in Tables 1 and 2. For Hanford sands and backfill soil, petrologic and particle size data was obtained from the near-field hydrology data package (Meyer et al. 2004). The specific surface area was inferred from the particle size data. Assuming spherical grains, the specific surface area $A_{m}$ is related to the particle radius $R_{m}$ by

$$
A_{m}=\frac{3 V_{r}}{R_{m}\left(1-\theta_{T}\right)}
$$

where $V_{r}$ is the relative volume and $\theta_{T}$ is the total porosity. 


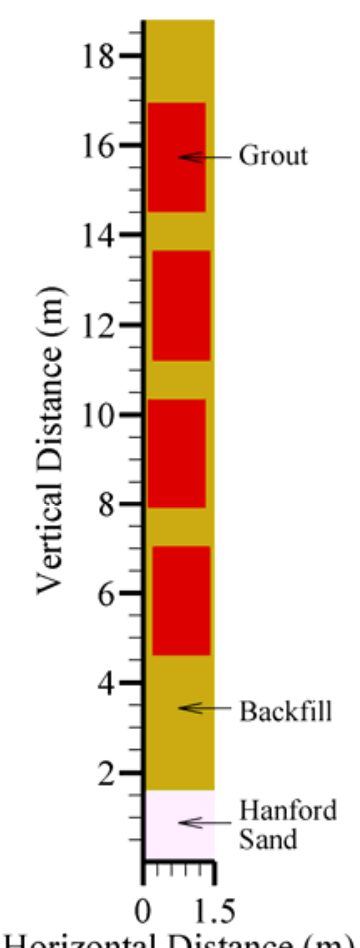

Figure 3. Lithographic Units for Grouted Secondary Waste Form Release Simulations

The assumed specific surface area for Hanford sediments and backfill soil are consistent with petrologic and particle size data obtained from laboratory-measured values (Serne et al. 1993). The specific surface area of the filler material in the WTP and bulk vitrification waste packages is assumed to be the same as that of the backfill.

Table 1. Relative Volume of Solid Species in Material Zones

\begin{tabular}{||l|c|c|c|c|c|c|c|c|c|c||}
\hline & Glass & Quartz & Albite & K-Feldspar & Illite & NaOH & $\begin{array}{c}\text { Ettringit } \\
\text { e }\end{array}$ & $\begin{array}{c}\text { Portlandit } \\
\text { e }\end{array}$ & $\begin{array}{c}\text { Tobermorite- } \\
\text { 14A }\end{array}$ & Mullite \\
\hline Hanford Sand & 0 & 0.4 & 0.4 & 0.1 & 0.1 & 0 & 0 & 0 & 0 & 0 \\
\hline Backfill & 0 & 0.4 & 0.4 & 0.1 & 0.1 & 0 & 0 & 0 & 0 & 0 \\
\hline $\begin{array}{l}\text { Refractory } \\
\text { Board }\end{array}$ & 0 & 0.4 & 0.4 & 0.1 & 0.1 & 0 & 0 & 0 & 0 & 0 \\
\hline Sand Insulation & 0 & 1 & 0 & 0 & 0 & 0 & 0 & 0 & 0 & 0 \\
\hline Cast Refractory & 0 & 0 & 0 & 0 & 0 & 0 & 0 & 0 & 0 & 1 \\
\hline Glass & 1 & 0 & 0 & 0 & 0 & 0 & 0 & 0 & 0 & 0 \\
\hline Filler & 0 & 0.4 & 0.4 & 0.1 & 0.1 & 0 & 0 & 0 & 0 & 0 \\
\hline Grout & 0 & 0 & 0 & 0 & 0 & 5 & 26 & 24 & 45 & 0 \\
\hline
\end{tabular}


Table 2. Specific Surface Area $\left(\mathrm{m}^{2} / \mathrm{m}^{3}\right)$ of Solid Species in Material Zones

\begin{tabular}{|c|c|c|c|c|c|c|c|c|c|c|}
\hline & $\begin{array}{l}\frac{\mathscr{z}}{0} \\
\frac{\pi}{U}\end{array}$ & 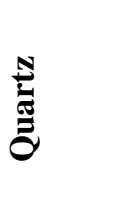 & 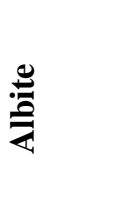 & 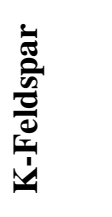 & 总 & 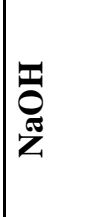 & 总 & 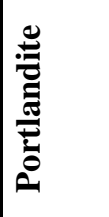 & 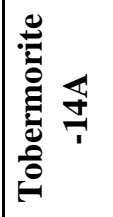 & 总 \\
\hline Hanford Sand & 0 & 8200 & 8,200 & 2,050 & 41,000 & 0 & 0 & 0 & 0 & 0 \\
\hline Backfill & 0 & 8200 & 8,200 & 2,050 & 41,000 & 0 & 0 & 0 & 0 & 0 \\
\hline Refractory Board & 0 & 8200 & 8,200 & 2,050 & 41,000 & 0 & 0 & 0 & 0 & 0 \\
\hline Sand Insulation & 0 & 20,000 & 0 & 0 & 0 & 0 & 0 & 0 & 0 & 0 \\
\hline Cast Refractory & 0 & 0 & 0 & 0 & 0 & 0 & 0 & 0 & 0 & 25,000 \\
\hline Glass & 50 & 0 & 0 & 0 & 0 & 0 & 0 & 0 & 0 & 0 \\
\hline Filler & 0 & 8200 & 8,200 & 2,050 & 41,000 & 0 & 0 & 0 & 0 & 0 \\
\hline Grout & 0 & 0 & 0 & 0 & 0 & 63 & 330 & 300 & 57 & 0 \\
\hline
\end{tabular}

The surface area assumed for the glass is consistent with the expected sparse degree of glass fracturing in the waste package based on prior experience with high-level waste glasses (Farnsworth et al. 1985; Peters and Slate 1981). Fracturing is expected to increase the glass surface area no more than 10 times its geometric surface area. The surface areas assumed for grout components were calculated from particle radii assumed for a grout from a proposed Italian waste repository (Bacon et al. 2002).

\subsubsection{Computational Grid}

The computational grid was set at $2 \mathrm{~cm}$ in vertical resolution; this is smaller than the $5 \mathrm{~cm}$ grid spacing used in the 2001 ILAW PA. The smaller grid spacing was used to resolve 1) the details in the bulk vitrification waste packages and 2) the backfill material between waste packages. The time step used in the calculations was calculated automatically by the code given a convergence criterion of $1 \times 10^{-6}$. This ensures that predicted values of aqueous species concentrations and mineral volumes are accurate between iterations for a given time step. If this cannot be achieved within a certain number of iterations, the time step is automatically reduced. Numerous simulations were conducted to ensure that the grid spacing and convergence criteria chosen for the simulations were small enough for accuracy yet large enough to allow the simulations to finish in a reasonable amount of time. For comparison, the base case remote-handled trench simulation was run with a grid spacing of $1 \mathrm{~cm}$ and a convergence criterion of $5 \times 10^{-7}$. Results from these simulations were not significantly different from those with the grid spacing and convergence criterion used in the simulations reported in this document.

\subsubsection{Material Hydraulic Properties}

The hydraulic properties for each lithographic unit in the simulation were determined in the near-field hydraulics data package (Meyer et al. 2004) or the far-field hydraulic properties data package (Khaleel 2004). These properties are also reported in Table 3. The hydraulic properties for the bulk

Table 3. Material Hydraulic Properties Used in Simulations 


\begin{tabular}{|l|c|c|c|c|c|c||}
\hline \hline \multicolumn{1}{|c|}{ Material } & $\begin{array}{c}\text { Particle } \\
\text { Density } \\
\text { (g/cm }\end{array}$ & $\begin{array}{c}\text { Saturated } \\
\text { Water } \\
\text { Content }\end{array}$ & $\begin{array}{c}\text { Residual } \\
\text { Water } \\
\text { Content }\end{array}$ & $\begin{array}{c}\text { van } \\
\text { Genuchten } \alpha \\
\mathbf{( c m}^{-1} \mathbf{~}\end{array}$ & $\begin{array}{c}\text { van } \\
\text { Genuchten n }\end{array}$ & $\begin{array}{c}\text { Saturated } \\
\text { Hydraulic } \\
\text { Conductivity } \\
\text { (cm/s) }\end{array}$ \\
\hline Hanford Sand & 2.63 & 0.394 & 0.049 & $6.31 \times 10^{-2}$ & 2.05 & $4.15 \times 10^{-3}$ \\
\hline Hanford Gravel & 2.63 & 0.138 & 0.010 & $2.10 \times 10^{-2}$ & 1.37 & $6.60 \times 10^{-4}$ \\
\hline Backfill & 2.71 & 0.350 & $3.00 \times 10^{-2}$ & $6.50 \times 10^{-2}$ & 1.70 & $4.91 \times 10^{-3}$ \\
\hline Refractory Board & 2.71 & 0.350 & $3.00 \times 10^{-2}$ & $6.50 \times 10^{-2}$ & 1.70 & $4.91 \times 10^{-3}$ \\
\hline Sand Insulation & 2.65 & 0.344 & $1.82 \times 10^{-2}$ & $3.70 \times 10^{-2}$ & 3.90 & $7.64 \times 10^{-3}$ \\
\hline Cast Refractory (matrix) & 3.10 & 0.170 & $6.29 \times 10^{-4}$ & $1.46 \times 10^{-2}$ & 2.47 & $3.80 \times 10^{-9}$ \\
\hline Cast Refractory (fracture) & 3.10 & 0.020 & $4.60 \times 10^{-4}$ & $2.00 \times 10^{-1}$ & 3.00 & $1.00 \times 10^{-2}$ \\
\hline Glass & 2.68 & 0.020 & $4.60 \times 10^{-4}$ & $2.00 \times 10^{-1}$ & 3.00 & $1.00 \times 10^{-2}$ \\
\hline Filler & 2.71 & 0.316 & $3.00 \times 10^{-2}$ & $6.50 \times 10^{-2}$ & 1.70 & $4.91 \times 10^{-3}$ \\
\hline Grout & 2.63 & 0.067 & $6.70 \times 10^{-5}$ & $3.87 \times 10^{-5}$ & 1.29 & $1.33 \times 10^{-9}$ \\
\hline
\end{tabular}

vitrification glass were assumed to be the same as for WTP glass (Meyer et al. 2004). Based on particle size data, the hydraulic properties for the insulating sand were estimated from a similar sand (Mualem 1976). The filler and refractory board hydraulic properties were assumed identical to backfill. For the cast refractory, unsaturated hydraulic properties for the matrix were taken from experimental data for clay brick ceramic (Hall and Hoff 2002). Hydraulic properties for the fractures were assumed to be the same as the glass fractures. Hydraulic properties for grout were assumed to be the same as the concrete properties (Meyer et al. 2004).

\subsubsection{Hydraulic Initial Conditions}

Initial hydraulic conditions for each lithographic unit include the following parameters:

- Water content

- Water flux

- Dissolved gas content of aqueous phase

- Gas pressure

- Relative humidity of gas phase

- Temperature.

The initial conditions were calculated by assuming a steady-state water flux at the upper boundary, which results in a steady-state water content distribution consistent with the hydraulic properties defined for each material. A spectrum of water flux rates ranging from 0.1 to $4.2 \mathrm{~mm} / \mathrm{yr}$ was used for different sensitivity cases. A constant subsurface temperature equal to the average ambient temperature of $15^{\circ} \mathrm{C}$ was assumed. The dissolved gas content of the aqueous phase was assumed to be negligible with respect to flow. The relative humidity of the gas phase was assumed to be $100 \%$.

\subsubsection{Hydraulic Boundary Conditions}


The following data are needed as a function of time and space along each boundary:

- Water flux

- Dissolved gas content of aqueous phase

- Gas pressure

- Relative humidity of gas phase

- $\quad$ Temperature.

The upper boundary is located just beneath the engineered barrier system (EBS) and was assigned a specified flux. A range of water flux rates, from $0.1 \mathrm{~mm} \mathrm{yr}^{-1}$ to $4.2 \mathrm{~mm} / \mathrm{yr}$, were used for different sensitivity cases. The lower bound of the recharge rates $\left(0.1 \mathrm{~mm} \mathrm{yr}^{-1}\right)$, was determined as a part of the recharge data package (Fayer and Szecsody 2004). The highest recharge rate (4.2 $\mathrm{mm} \mathrm{yr}^{-1}$ ) was implemented in the previous ILAW PA (Mann et al. 2001) and is provided here for comparison. The Hanford Site Configuration Group has decided to introduce conservatism into the recharge rate when a barrier is used. Thus, the value of $0.1 \mathrm{~mm} \mathrm{yr}^{-1}$ recommended by the Recharge Data Package for the 2005 Integrated Disposal Facility Performance Assessment (Fayer and Szecsody 2004) was increased by a factor of 5. However, these simulations were started during a period of debate when the recommended

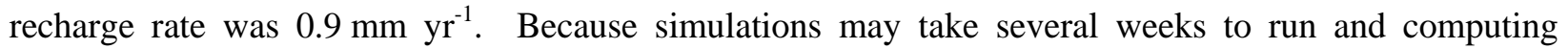
resources are limited, a decision was made to continue to use $0.9 \mathrm{~mm} \mathrm{yr}^{-1}$ as the base case.

The location of the lower model boundary was selected so that horizontal gradients are small. The lower boundary is a free drainage boundary $4.5 \mathrm{~m}$ below the lowest layer of backfill. For hydraulic boundary conditions at this lower boundary, free drainage under gravity will be assumed. Also, the side boundaries are placed at axes of symmetry so that no-flow boundaries can be assumed.

A constant subsurface temperature, equal to the average ambient temperature of $15^{\circ} \mathrm{C}$ was assumed. The dissolved gas content of the aqueous phase was assumed to be negligible with respect to flow. The relative humidity of the gas phase was assumed to be $100 \%$.

\subsubsection{Solute Transport Coefficients}

For each gaseous and aqueous species, the following data are needed:

- Aqueous diffusion coefficient $\left(\mathrm{m}^{2} \mathrm{~s}^{-1}\right)$

- Gas diffusion coefficient $\left(\mathrm{m}^{2} \mathrm{~s}^{-1}\right)$ or an assumption that the gas partial pressure is fixed.

The aqueous diffusion coefficients were assumed to be $5 \times 10^{-9} \mathrm{~m}^{2} / \mathrm{s}$ for all aqueous species (Mann et al. 1998). The gas partial pressure for $\mathrm{CO}_{2}$ and $\mathrm{O}_{2}$ were fixed at atmospheric values of $3 \times 10^{-4}$ and $2.1 \times 10^{-1} \mathrm{~atm}$, respectively, so no gaseous diffusion coefficient was specified.

\subsection{Chemistry Input}




\subsubsection{Aqueous Species}

Aqueous species are the cations, anions, or neutral complexes present in the aqueous phase. For each aqueous species, the following data are needed:

- Molecular weight

- Charge

- Hard core diameter

- Number of elements in aqueous species

- Stoichiometric coefficient of each element.

The aqueous species listed in Table 4 were identified by simulating the dissolution of waste glass in deionized water at $15^{\circ} \mathrm{C}$ with the EQ3/6 code package (Wolery and Daveler 1992). All data were obtained from the EQ3/6 data0.com.R8 database (Daveler and Wolery 1992). The EQ3/6 software was used to extract a subset of aqueous (and solid) species from the large thermodynamic database that were relevant for the reactive transport simulations.

Table 4. Key Aqueous Species Produced by the Dissolution of Waste Glass and Grout

\begin{tabular}{|c|c|c|}
\hline Species & Mol. Wt. & Hard-Core Diameter \\
\hline $\mathrm{AlO}_{2}^{-}$ & 58.98 & 4.0 \\
\hline $\mathrm{Ag}^{+}$ & 107.9 & 2.5 \\
\hline $\mathrm{Ba}^{2+}$ & 137.3 & 5.0 \\
\hline $\mathrm{B}(\mathrm{OH})_{3}(\mathrm{aq})$ & 61.83 & 3.0 \\
\hline $\mathrm{Ca}^{2+}$ & 40.08 & 6.0 \\
\hline $\mathrm{CO}_{2}(\mathrm{aq})$ & 44.01 & 3.0 \\
\hline $\mathrm{CO}_{3}{ }^{2-}$ & 60.01 & 5.0 \\
\hline $\mathrm{CrO}_{4}{ }^{2-}$ & 115.99 & 4.0 \\
\hline $\mathrm{Fe}(\mathrm{OH})_{3}(\mathrm{aq})$ & 106.87 & 3.0 \\
\hline $\mathrm{H}_{2} \mathrm{O}$ & 18.01 & 3.0 \\
\hline $\mathrm{H}_{2} \mathrm{SiO}_{4}{ }^{2-}$ & 94.10 & 4.0 \\
\hline $\mathrm{H}^{+}$ & 1.01 & 9.0 \\
\hline $\mathrm{HCO}_{3}^{-}$ & 61.02 & 4.0 \\
\hline $\mathrm{HCrO}_{4}^{-}$ & 117.00 & 4.0 \\
\hline $\mathrm{HsiO}_{3}^{-}$ & 77.09 & 4.0 \\
\hline $\mathrm{I}^{-}$ & 126.90 & 3.0 \\
\hline $\mathrm{IO}_{3}^{-}$ & 174.90 & 4.0 \\
\hline $\mathrm{K}^{+}$ & 39.10 & 3.0 \\
\hline $\mathrm{KOH}(\mathrm{aq})$ & 56.10 & 0.0 \\
\hline $\mathrm{La}^{3+}$ & 138.91 & 9.0 \\
\hline $\mathrm{Mg}^{2+}$ & 24.31 & 8.0 \\
\hline
\end{tabular}

Table 4 (contd)

\begin{tabular}{l|l|l|}
\hline Species & Mol. Wt. & Hard-Core Diameter \\
\hline
\end{tabular}




\begin{tabular}{|c|c|c|}
\hline $\mathrm{MgB}(\mathrm{OH})_{4}^{+}$ & 103.15 & 4.0 \\
\hline $\mathrm{MgCO}_{3}(\mathrm{aq})$ & 84.31 & 0.0 \\
\hline $\mathrm{MgHCO}_{3}{ }^{+}$ & 85.32 & 4.0 \\
\hline $\mathrm{Na}^{+}$ & 22.99 & 4.0 \\
\hline $\mathrm{NaB}(\mathrm{OH})_{4}(\mathrm{aq})$ & 101.83 & 3.0 \\
\hline $\mathrm{NaCO}_{3}^{-}$ & 83.00 & 4.0 \\
\hline $\mathrm{NaHCO}_{3}(\mathrm{aq})$ & 84.01 & 3.0 \\
\hline $\mathrm{NaHSiO}_{3}(\mathrm{aq})$ & 100.08 & 0.0 \\
\hline $\mathrm{NaOH}(\mathrm{aq})$ & 40.00 & 3.0 \\
\hline $\mathrm{Ni}^{2+}$ & 58.69 & 4.5 \\
\hline $\mathrm{O}_{2}(\mathrm{aq})$ & 32.00 & 3.0 \\
\hline $\mathrm{OH}^{-}$ & 17.01 & 3.0 \\
\hline $\mathrm{PuO}_{2}\left(\mathrm{CO}_{3}\right)_{3}{ }^{4-}$ & 456.03 & 4.0 \\
\hline $\mathrm{SeO}_{4}^{2-}$ & 142.96 & 4.0 \\
\hline $\mathrm{SiO}_{2}$ (aq) & 60.08 & 3.0 \\
\hline $\mathrm{TcO}_{4}^{-}$ & 162.00 & 4.0 \\
\hline $\mathrm{Ti}(\mathrm{OH})_{4}(\mathrm{aq})$ & 115.91 & 3.0 \\
\hline $\mathrm{UO}_{2}\left(\mathrm{CO}_{3}\right)_{2}{ }^{2-}$ & 390.05 & 4.0 \\
\hline $\mathrm{UO}_{2}\left(\mathrm{CO}_{3}\right)_{3}{ }^{4-}$ & 450.06 & 4.0 \\
\hline $\mathrm{UO}_{2}(\mathrm{OH})_{2}(\mathrm{aq})$ & 304.04 & 3.0 \\
\hline $\mathrm{Zn}(\mathrm{OH})_{3}^{-}$ & 116.41 & 4.0 \\
\hline $\mathrm{Zn}^{2+}$ & 65.39 & 6.0 \\
\hline $\mathrm{ZnOH}^{+}$ & 82.40 & 4.0 \\
\hline $\mathrm{Zr}(\mathrm{OH})_{4}(\mathrm{aq})$ & 159.25 & 3.0 \\
\hline
\end{tabular}

\subsubsection{Gas Species}

Gas species are compounds such as $\mathrm{CO}_{2}$ and $\mathrm{O}_{2}$ that make up the air phase in STORM simulations. For each gas species, the following data are needed. Only $\mathrm{CO}_{2}$ and $\mathrm{O}_{2}$ are expected to influence the chemical environment significantly in the near and far fields.

- Molecular weight

- Number of elements in gaseous species

- Stoichiometric coefficient of each element.

\subsubsection{Solid Species}

For each solid species, including any secondary minerals that precipitate from supersaturated conditions, the mass density $\left(\mathrm{g} \mathrm{cm}^{-3}\right)$ and the stoichiometric coefficient of each element are needed. The simulation results in the following sections reference several waste glasses (Table 5): three WTP glasses (LAWA44, LAWB45, and LAWC22), and two bulk vitrification glasses (six-tank composite and S-109). The grout is assumed to be composed of tobermorite-14A (representing CSH gel), ettringite, portlandite,

Table 5. Composition (mole fraction) of Glasses Used in Simulations

\section{\begin{tabular}{|l|l|l|l|l|l|l|} 
Element & LAWA44 & LAWB45 & LAWC22 & LAWABP1 & BV 6-Tank & BV S-109 \\
\hline
\end{tabular}}




\begin{tabular}{|l|c|c|c|c|c|c||}
\hline \multicolumn{1}{|c|}{ Element } & LAWA44 & LAWB45 & LAWC22 & LAWABP1 & BV 6-Tank & BV S-109 \\
\hline $\mathrm{Al}$ & $8.15 \mathrm{E}-02$ & $7.51 \mathrm{E}-02$ & $7.67 \mathrm{E}-02$ & $1.36 \mathrm{E}-01$ & $1.22 \mathrm{E}-01$ & $1.22 \mathrm{E}-01$ \\
\hline $\mathrm{B}$ & $1.71 \mathrm{E}-01$ & $2.21 \mathrm{E}-01$ & $1.86 \mathrm{E}-01$ & $1.84 \mathrm{E}-01$ & $9.76 \mathrm{E}-02$ & $9.78 \mathrm{E}-02$ \\
\hline $\mathrm{Ba}$ & & & & & $2.22 \mathrm{E}-04$ & $2.22 \mathrm{E}-04$ \\
\hline $\mathrm{Bi}$ & & & $8.28 \mathrm{E}-06$ & & & \\
\hline $\mathrm{Ca}$ & $2.38 \mathrm{E}-02$ & $7.38 \mathrm{E}-02$ & $5.87 \mathrm{E}-02$ & & $3.32 \mathrm{E}-02$ & $3.37 \mathrm{E}-02$ \\
\hline $\mathrm{Cl}$ & $1.23 \mathrm{E}-02$ & $1.06 \mathrm{E}-04$ & $1.61 \mathrm{E}-03$ & $1.13 \mathrm{E}-02$ & $3.45 \mathrm{E}-03$ & $5.76 \mathrm{E}-04$ \\
\hline $\mathrm{Cr}$ & $1.76 \mathrm{E}-04$ & $6.00 \mathrm{E}-04$ & $1.78 \mathrm{E}-04$ & $1.82 \mathrm{E}-04$ & $8.94 \mathrm{E}-04$ & $1.16 \mathrm{E}-03$ \\
\hline $\mathrm{Cs}$ & & $8.87 \mathrm{E}-06$ & & & & \\
\hline $\mathrm{F}$ & $3.53 \mathrm{E}-04$ & $2.66 \mathrm{E}-03$ & $5.48 \mathrm{E}-03$ & $1.46 \mathrm{E}-03$ & $2.50 \mathrm{E}-03$ & $3.58 \mathrm{E}-04$ \\
\hline $\mathrm{Fe}$ & $5.86 \mathrm{E}-02$ & $4.11 \mathrm{E}-02$ & $4.37 \mathrm{E}-02$ & $2.16 \mathrm{E}-02$ & $3.62 \mathrm{E}-02$ & $3.70 \mathrm{E}-02$ \\
\hline $\mathrm{K}$ & $7.11 \mathrm{E}-03$ & $3.45 \mathrm{E}-03$ & $1.30 \mathrm{E}-03$ & $3.23 \mathrm{E}-02$ & $2.22 \mathrm{E}-02$ & $2.18 \mathrm{E}-02$ \\
\hline $\mathrm{La}$ & & & $7.89 \mathrm{E}-06$ & $8.48 \mathrm{E}-03$ & & \\
\hline $\mathrm{Li}$ & & $1.93 \mathrm{E}-01$ & $1.08 \mathrm{E}-01$ & & & \\
\hline $\mathrm{Mg}$ & $3.31 \mathrm{E}-02$ & $4.60 \mathrm{E}-02$ & $2.41 \mathrm{E}-02$ & $1.71 \mathrm{E}-02$ & $2.26 \mathrm{E}-02$ & $2.28 \mathrm{E}-02$ \\
\hline $\mathrm{Mn}$ & & & $3.35 \mathrm{E}-04$ & & $6.70 \mathrm{E}-04$ & $6.72 \mathrm{E}-04$ \\
\hline $\mathrm{Mo}$ & $4.65 \mathrm{E}-05$ & & & & & \\
\hline $\mathrm{Na}$ & $4.32 \mathrm{E}-01$ & $1.31 \mathrm{E}-01$ & $2.99 \mathrm{E}-01$ & $4.46 \mathrm{E}-01$ & $4.38 \mathrm{E}-01$ & $4.39 \mathrm{E}-01$ \\
\hline $\mathrm{Ni}$ & & & $2.58 \mathrm{E}-04$ & & & \\
\hline $\mathrm{O}$ & $1.83 \mathrm{E}+00$ & $1.86 \mathrm{E}+00$ & $1.83 \mathrm{E}+00$ & & $1.85 \mathrm{E}+00$ & $1.85 \mathrm{E}+00$ \\
\hline $\mathrm{P}$ & $2.83 \mathrm{E}-04$ & $2.64 \mathrm{E}-04$ & $1.58 \mathrm{E}-03$ & $7.79 \mathrm{E}-04$ & $5.26 \mathrm{E}-03$ & $5.76 \mathrm{E}-03$ \\
\hline $\mathrm{Pb}$ & & & $6.05 \mathrm{E}-05$ & & & \\
\hline $\mathrm{S}$ & $8.37 \mathrm{E}-04$ & $6.58 \mathrm{E}-03$ & $2.74 \mathrm{E}-03$ & $8.63 \mathrm{E}-04$ & $7.13 \mathrm{E}-03$ & $2.89 \mathrm{E}-03$ \\
\hline $\mathrm{Si}$ & $4.97 \mathrm{E}-01$ & $4.98 \mathrm{E}-01$ & $4.99 \mathrm{E}-01$ & $4.82 \mathrm{E}-01$ & $5.23 \mathrm{E}-01$ & $5.31 \mathrm{E}-01$ \\
\hline $\mathrm{Sr}$ & & & $2.48 \mathrm{E}-06$ & & & \\
\hline $\mathrm{Tc}$ & $2.77 \mathrm{E}-04$ & $2.58 \mathrm{E}-05$ & $2.66 \mathrm{E}-05$ & & $4.38 \mathrm{E}-04$ & $4.39 \mathrm{E}-04$ \\
\hline $\mathrm{Ti}$ & $1.67 \mathrm{E}-02$ & & $9.20 \mathrm{E}-03$ & $2.15 \mathrm{E}-02$ & $6.72 \mathrm{E}-03$ & $6.82 \mathrm{E}-03$ \\
\hline $\mathrm{Zn}$ & $2.44 \mathrm{E}-02$ & $2.42 \mathrm{E}-02$ & $2.43 \mathrm{E}-02$ & $2.21 \mathrm{E}-02$ & & \\
\hline $\mathrm{Zr}$ & $1.63 \mathrm{E}-02$ & $1.60 \mathrm{E}-02$ & $1.58 \mathrm{E}-02$ & $2.94 \mathrm{E}-02$ & $3.86 \mathrm{E}-02$ & $3.87 \mathrm{E}-02$ \\
\hline $\mathrm{Mass}$ density, g cm & 2.67 & 2.67 & 2.70 & 2.68 & 2.71 & 2.67 \\
\hline & & & & & & \\
\hline & & & & & & \\
\hline
\end{tabular}

and sodium hydroxide (Table 6) (Bacon et al. 2002). The compositions of materials that make up the backfill, filler, Hanford soil, and cast refractory used in the simulations are listed in Table 7 (Serne et al. 1993). The mass density is obtained by dividing the molecular weight by the molar volume of the compound.

Secondary phases are solids that precipitate from a supersaturated aqueous solution. A list of potential secondary phases that form from long-term weathering experiments with the various waste glass formulations and from modeling the solution chemistry observed in experiments with the EQ3/6 code is provided in Pierce et al. (2004a, 2004b). A large number of phases were eliminated from consideration because 1) formation of the phase is kinetically prohibited at the disposal system temperature of $15^{\circ} \mathrm{C}$, 2) selection of the phase would violate the Gibbs phase rule, 3) simulations show that allowing the phase to form is inconsistent with a large body of laboratory test data with borosilicate glasses, or 4) the phase is unstable over the range of chemical environments expected for the IDF system. 
Table 6. Composition of Grout Used in Simulations

\begin{tabular}{||l|l|c|c||}
\hline \multicolumn{1}{|c|}{ Species } & \multicolumn{1}{|c|}{ Formula } & \multicolumn{1}{|c||}{$\begin{array}{c}\text { Mol. Wt. } \\
\mathbf{g ~ m o l}^{-1}\end{array}$} & $\begin{array}{c}\text { Molar Volume } \\
\mathbf{c m}^{3} \text { mol }^{-1}\end{array}$ \\
\hline Sodium hydroxide & $\mathrm{NaOH}$ & 40.0 & 19.0 \\
\hline Ettringite & $\mathrm{Ca}_{6} \mathrm{Al}_{2}\left(\mathrm{SO}_{4}\right)_{3}(\mathrm{OH})_{12} \cdot 26 \mathrm{H}_{2} \mathrm{O}$ & 1255.1 & 738.3 \\
\hline Portlandite & $\mathrm{Ca}(\mathrm{OH})_{2}$ & 74.1 & 33.1 \\
\hline Tobermorite-14A & $\mathrm{Ca}_{6} \mathrm{Si}_{6} \mathrm{O}_{16}(\mathrm{OH})_{2} \cdot 4 \mathrm{H}_{2} \mathrm{O}$ & 830.1 & 345.9 \\
\hline Silver Iodide & $\mathrm{AgI}$ & 234.8 & 41.1 \\
\hline Barium Iodate & $\mathrm{Ba}\left(\mathrm{IO}_{3}\right)_{2}$ & 487.1 & 103.6 \\
\hline Barium Iodide & $\mathrm{BaI}_{2}$ & 391.1 & 76.0 \\
\hline
\end{tabular}

Table 7. Composition of Native and Surrounding Materials Used in Simulations

\begin{tabular}{||l|l|c|c||}
\hline \multicolumn{1}{|c|}{ Species } & \multicolumn{1}{|c|}{ Formula } & $\begin{array}{c}\text { Mol. Wt. } \\
\mathbf{g ~ m o l}^{\mathbf{1}}\end{array}$ & $\begin{array}{c}\text { Molar Volume, } \\
\mathbf{c m}^{\mathbf{3}} \mathbf{~ m o l}^{\mathbf{1}}\end{array}$ \\
\hline Albite & $\mathrm{NaAlSi}_{3} \mathrm{O}_{8}$ & 262.2 & 100.4 \\
\hline Illite & $\mathrm{K}_{0.6} \mathrm{Mg}_{0.25} \mathrm{Al}_{1.8} \mathrm{Al}_{0.5} \mathrm{Si}_{3.5} \mathrm{O}_{10}(\mathrm{OH})_{2}$ & 383.9 & 500.0 \\
\hline K-Feldspar & $\mathrm{KAlSi}_{3} \mathrm{O}_{8}$ & 278.3 & 108.8 \\
\hline Quartz & $\mathrm{SiO}_{2}$ & 60.1 & 22.6 \\
\hline Mullite & $3\left(\mathrm{Al}_{2} \mathrm{O}_{3}\right) 2\left(\mathrm{SiO}_{2}\right)$ & 426.1 & 137.4 \\
\hline
\end{tabular}

The final phase assemblage used in STORM simulations (see Table 8) was further constrained because preliminary runs showed that the phase never formed or formed in such small amounts that the effects were insignificant. The composition of the secondary minerals used in the simulations is listed in Table 8. The mass density is obtained by dividing the molecular weight by the molar volume of the solid.

Table 8. Composition of Secondary Minerals Used in Simulations

\begin{tabular}{|c|c|c|c|}
\hline Species & Formula & Mol. Wt. & Molar Volume \\
\hline Analcime & $\mathrm{Na}_{0.96} \mathrm{Al}_{0.96} \mathrm{Si}_{2.04} \mathrm{O}_{6}$ & 201.2 & 96.8 \\
\hline Anatase & $\mathrm{TiO}_{2}$ & 79.8 & 20.5 \\
\hline Baddeleyite & $\mathrm{ZrO}_{2}$ & 123.2 & 21.9 \\
\hline Calcite & $\mathrm{CaCO}_{3}$ & 100.1 & 36.9 \\
\hline Chalcedony & $\mathrm{SiO}_{2}$ & 60.1 & 22.7 \\
\hline Clinochlore-14A & $\mathrm{Mg}_{5} \mathrm{Al}_{2} \mathrm{Si}_{3} \mathrm{O}_{10}(\mathrm{OH})_{8}$ & 555.8 & 207.1 \\
\hline $\mathrm{Fe}(\mathrm{OH})_{3}(\mathrm{am})$ & $\mathrm{Fe}(\mathrm{OH})_{3}$ & 106.9 & 34.4 \\
\hline Gibbsite & $\mathrm{Al}(\mathrm{OH})_{3}$ & 78.0 & 31.9 \\
\hline Gypsum & $\mathrm{CaSO}_{4}$ & 172.2 & 74.7 \\
\hline $\mathrm{La}(\mathrm{OH}) 3$ & $\mathrm{La}(\mathrm{OH})_{3}$ & 189.9 & 54.5 \\
\hline Nontronite-Na & $\mathrm{Na}_{0.33} \mathrm{Fe}_{2} \mathrm{Al}_{0.33} \mathrm{Si}_{3.67} \mathrm{O}_{11} \cdot \mathrm{H}_{2} \mathrm{O}$ & 425.2 & 184.9 \\
\hline $\mathrm{PuO} 2$ & $\mathrm{PuO}_{2}$ & 276.0 & 23.8 \\
\hline Sepiolite & $\mathrm{Mg}_{4} \mathrm{Si}_{6} \mathrm{O}_{15}(\mathrm{OH})_{2}: 6 \mathrm{H}_{2} \mathrm{O}$ & 647.8 & 285.6 \\
\hline $\mathrm{SiO}_{2}(\mathrm{am})$ & $\mathrm{SiO}_{2}$ & 60.1 & 29.0 \\
\hline Soddyite & $\left(\mathrm{UO}_{2}\right) 2\left(\mathrm{SiO}_{4}\right): 2 \mathrm{H}_{2} \mathrm{O}$ & 668.1 & 131.2 \\
\hline Theophrasite & $\mathrm{Ni}(\mathrm{OH})_{2}$ & 92.7 & 22.3 \\
\hline Weeksite & $\mathrm{K}_{2}\left(\mathrm{UO}_{2}\right)_{2} \mathrm{Si}_{6} \mathrm{O}_{15} \cdot 4 \mathrm{H}_{2} \mathrm{O}$ & 1098.8 & 273.5 \\
\hline $\mathrm{Zn}(\mathrm{OH})_{2}$ (gamma) & $\mathrm{Zn}(\mathrm{OH})_{2}$ & 99.4 & 30.0 \\
\hline
\end{tabular}




\subsubsection{Equilibrium Reactions}

For each equilibrium reaction, the stoichiometric coefficient of each aqueous species in each reaction and the equilibrium constant at a temperature of $15^{\circ} \mathrm{C}$ are needed. The equilibrium reactions in Table 9 were identified by simulating the dissolution of the waste glasses and grout in deionized water at $15^{\circ} \mathrm{C}$ with the EQ3/6 code package (Wolery and Daveler 1992) and the data0.com.R8 database (Daveler and Wolery 1992; Wolery and Daveler 1992). A significant number of secondary aqueous species were excluded from the simulations because their concentrations were extremely small over the range of chemical conditions anticipated for the ILAW disposal system.

Table 9. Equilibrium Reactions at $15^{\circ} \mathrm{C}$

\begin{tabular}{|c|c|}
\hline Reaction & $\log K$ \\
\hline $\mathrm{BO}_{2}^{-}+\mathrm{H}_{2} \mathrm{O}+\mathrm{H}^{+}=\mathrm{B}(\mathrm{OH})_{3}(\mathrm{aq})$ & 9.35 \\
\hline $\mathrm{CO}_{2}(\mathrm{aq})+\mathrm{H}_{2} \mathrm{O}=\mathrm{H}^{+}+\mathrm{HCO}_{3}^{-}$ & -6.42 \\
\hline $\mathrm{CO}_{3}^{2-}+\mathrm{H}^{+}=\mathrm{HCO}_{3}^{-}$ & 10.43 \\
\hline $\mathrm{CaB}(\mathrm{OH})_{4}^{+}=\mathrm{OH}^{-}+\mathrm{B}(\mathrm{OH})_{3}(\mathrm{aq})+\mathrm{Ca}^{2+}$ & -6.92 \\
\hline $\mathrm{CaCO}_{3}(\mathrm{aq})+\mathrm{H}_{2} \mathrm{O}=\mathrm{OH}^{-}+\mathrm{HCO}_{3}^{-}+\mathrm{Ca}^{2+}$ & -7.15 \\
\hline $\mathrm{CaHCO}_{3}^{+}=\mathrm{HCO}_{3}^{-}+\mathrm{Ca}^{2+}$ & -1.05 \\
\hline $\mathrm{CaOH}^{+}=\mathrm{OH}^{-}+\mathrm{Ca}^{2+}$ & -1.49 \\
\hline $\mathrm{H}_{2} \mathrm{SiO}_{4}{ }^{2-}+\mathrm{H}^{+}=2 \mathrm{H}_{2} \mathrm{O}+\mathrm{SiO}_{2}(\mathrm{aq})$ & 22.96 \\
\hline $\mathrm{HCrO}_{4}^{-}=\mathrm{CrO}_{4}^{2-}+\mathrm{H}^{+}$ & -6.49 \\
\hline $\mathrm{HSiO}_{3}^{-}+\mathrm{H}^{+}=\mathrm{SiO}_{2}(\mathrm{aq})+\mathrm{H}_{2} \mathrm{O}$ & 10.10 \\
\hline $\mathrm{KOH}(\mathrm{aq})+\mathrm{H}^{+}=\mathrm{H}_{2} \mathrm{O}+\mathrm{K}^{+}$ & 14.46 \\
\hline $\mathrm{LaCO}_{3}^{+}+\mathrm{H}^{+}=\mathrm{HCO}_{3}^{-}+\mathrm{La}^{3+}$ & 9.13 \\
\hline $\mathrm{MgB}(\mathrm{OH})_{4}^{+}+\mathrm{H}^{+}=\mathrm{H}_{2} \mathrm{O}+\mathrm{B}(\mathrm{OH})_{3}(\mathrm{aq})+\mathrm{Mg}^{2+}$ & 7.35 \\
\hline $\mathrm{MgCO}_{3}(\mathrm{aq})+\mathrm{H}^{+}=\mathrm{HCO}_{3}^{-}+\mathrm{Mg}^{2+}$ & 7.50 \\
\hline $\mathrm{MgHCO}_{3}{ }^{+}=\mathrm{HCO}_{3}^{-}+\mathrm{Mg}^{2+}$ & -1.04 \\
\hline $\mathrm{NaB}(\mathrm{OH})_{4}(\mathrm{aq})+\mathrm{H}^{+}=\mathrm{B}(\mathrm{OH})_{3}(\mathrm{aq})+\mathrm{Na}^{+}+\mathrm{H}_{2} \mathrm{O}$ & 8.97 \\
\hline $\mathrm{NaCO}_{3}^{-}+\mathrm{H}^{+}=\mathrm{HCO}_{3}^{-}+\mathrm{Na}^{+}$ & 9.82 \\
\hline $\mathrm{NaHCO}_{3}(\mathrm{aq})=\mathrm{HCO}_{3}^{-}+\mathrm{Na}^{+}$ & -0.24 \\
\hline $\mathrm{NaHSiO}_{3}(\mathrm{aq})+\mathrm{H}^{+}=\mathrm{Na}^{+}+\mathrm{SiO}_{2}(\mathrm{aq})+\mathrm{H}_{2} \mathrm{O}$ & 8.36 \\
\hline $\mathrm{NaOH}(\mathrm{aq})+\mathrm{H}^{+}=\mathrm{Na}^{+}+\mathrm{H}_{2} \mathrm{O}$ & 15.12 \\
\hline $\mathrm{OH}^{-}+\mathrm{H}^{+}=\mathrm{H}_{2} \mathrm{O}$ & 14.34 \\
\hline $\mathrm{UO}_{2}\left(\mathrm{CO}_{3}\right)_{3}{ }^{4-}+2 \mathrm{H}_{2} \mathrm{O}+\mathrm{H}^{+} \rightleftharpoons 3 \mathrm{HCO}_{3}{ }^{-}+\mathrm{UO}_{2}(\mathrm{OH}) 2(\mathrm{aq})$ & -0.97 \\
\hline $\mathrm{UO}_{2}\left(\mathrm{CO}_{3}\right)_{2}^{2-}+2 \mathrm{H}_{2} \mathrm{O} \rightleftharpoons 2 \mathrm{HCO}_{3}^{-}+\mathrm{UO}_{2}(\mathrm{OH}) 2(\mathrm{aq})$ & 6.52 \\
\hline
\end{tabular}

\subsubsection{Kinetic Reactions}

For each kinetic reaction, the following data are needed:

- Mass-action law type: full, reduced, glass

- Stoichiometric coefficient of aqueous species in each reaction

- Equilibrium constant at a temperature of $15^{\circ} \mathrm{C}$.

- Rate constant of reaction. 
A full mass-action law type will be used for each solid phase except the waste glass. A special massaction law type implemented in the STORM code will be used for the glass and is discussed in the following section.

Compilations of kinetic rate constants equivalent to thermodynamic databases for important mineral phases are not available. Also, the available mineral dissolution/precipitation kinetics data are much more limited than thermodynamic data. Consequently, sufficiently large rate constants will be used to approximate equilibrium conditions, that is, to ensure that the phase will precipitate rapidly if the local chemical environment at a grid node is saturated with respect to the particular phase.

\subsubsection{Glass Rate Law}

For a dissolution reaction involving glass, parameters associated with the following kinetic rate law are needed:

$$
r_{g}=\vec{k} a_{\mathrm{H}^{+}}^{-\eta} e \frac{-E_{a}}{\mathrm{RT}}\left[1-\left(\frac{Q}{K_{g}}\right)^{\sigma}\right]
$$

where

$$
\begin{aligned}
r_{\underline{g}} & =\text { dissolution rate, } \mathrm{g} \mathrm{m}^{-2} \mathrm{~d}^{-1} \\
\vec{k} & =\text { intrinsic rate constant, } \mathrm{g} \mathrm{m}^{-2} \mathrm{~d}^{-1} \\
a_{\mathrm{H}^{+}} & =\text {hydrogen ion activity (variable to be calculated by STORM) } \\
E_{a} & =\text { activation energy, } \mathrm{kJ} / \mathrm{mol} \\
R & =\text { gas constant, } \mathrm{kJ} /(\mathrm{mol} \cdot \mathrm{K}) \\
T & =\text { temperature, } \mathrm{K}\left(\text { assumed constant at } 15^{\circ} \mathrm{C}\right) \\
Q & =\text { ion activity product for Glass (variable to be calculated by STORM) } \\
K_{g} & =\text { pseudo-equilibrium constant } \\
\eta & =\text { pH power law coefficient } \\
\sigma & =\text { Temkin coefficient }(\sigma=1 \text { assumed). }
\end{aligned}
$$

Equation (2) is an approximation for glass because glass is metastable and the reaction proceeds one way (i.e., glass dissolves). The unknown parameters in Equation (2) ( $\vec{k}, E_{a}, K_{g}$, and $\eta$ ) have been determined for LAW glasses (Pierce et al. 2004a) and bulk vitrification glasses (Pierce et al. 2004b); these values are given in Table 10.

Test results with LAW and bulk vitrification glasses (excluding LAWB45) show that it is susceptible to a secondary reaction mechanism, alkali ion exchange. This reaction results in the selective extraction of Na via the reaction:

$$
\text { LAWA44-Na }+\mathrm{H}^{+} \rightarrow \text { LAWA44-H }+\mathrm{Na}^{+}
$$

where LAWA44-Na represents the unreacted glass containing Na and LAWA44-H represents a hydrated glass where the $\mathrm{Na}$ has been replaced with an equimolar amount of hydrogen. The rate of this reaction 
Table 10. Summary of Kinetic Rate Parameters Used for Glasses

\begin{tabular}{|l|l|c|c|c|c|c|c|}
\hline Parameter & \multicolumn{1}{|c|}{ Meaning } & LAWA44 & LAWB45 & LAWC22 & LAWABP1 & BV 6-Tank & BV S-109 \\
\hline \hline$\vec{k}$ & $\begin{array}{l}\text { Intrinsic rate constant, } \\
\text { mol m } \mathrm{s}^{-1}\end{array}$ & $2.2 \times 10^{-3}$ & $3.0 \times 10^{-3}$ & $1.8 \times 10^{-2}$ & $5.7 \times 10^{-1}$ & $1.7 \times 10^{-1}$ & $7.3 \times 10^{-3}$ \\
\hline$K_{g}$ & $\begin{array}{l}\text { Apparent equilibrium } \\
\text { constant for glass } \\
\text { based on activity of } \\
\text { SiO }(\text { aq) }\end{array}$ & $10^{-3.26}$ & $10^{-3.28}$ & $10^{-3.28}$ & $10^{-3.31}$ & $10^{-2.85}$ & $10^{-3.32}$ \\
\hline$\eta$ & $\begin{array}{l}\mathrm{pH} \text { power law } \\
\text { coefficient }\end{array}$ & 0.49 & 0.34 & 0.42 & 0.35 & 0.5 & 0.53 \\
\hline$E_{a}$ & $\begin{array}{l}\text { Activation energy of } \\
\text { glass dissolution } \\
\text { reaction, kJ/mol }\end{array}$ & 60 & 53 & 64 & 68 & 75 & 69 \\
\hline$r_{x}$ & $\begin{array}{l}\text { Na ion-exchange rate, } \\
\text { mol m } \text { s }^{-1}\end{array}$ & $5.3 \times 10^{-11}$ & 0 & $1.2 \times 10^{-10}$ & $3.4 \times 10^{-11}$ & $4.0 \times 10^{-11}$ & $2.3 \times 10^{-10}$ \\
\hline
\end{tabular}

has been determined from single-pass flow-through experiments (Pierce et al. 2004a; Pierce et al. 2004b). STORM keeps track of the amount of hydrated glass formed via reaction (3) and then allows it to dissolve according to the same kinetic rate law (reaction 2) as the parent glass.

\subsubsection{Bulk Vitrification Surrounding Materials}

The bulk vitrification waste glass is enveloped by cast refractory. Based on $\mathrm{x}$-ray diffraction analysis, the cast refractory was assumed to consist of mullite, $3\left(\mathrm{Al}_{2} \mathrm{O}_{3}\right) 2\left(\mathrm{SiO}_{2}\right)$ (Pierce et al. 2004b). Geochemical parameters for mullite were determined from product consistency tests (Pierce et al. 2004b) and are given in Table 11, although the equilibrium constant was estimated from published thermodynamic data (Robie et al. 1978).

Table 11. Kinetic and Equilibrium Geochemical Parameters for Mullite

\begin{tabular}{||c|c|c||}
\hline \hline Symbol & Parameter & Value \\
\hline $\mathrm{k}$ & intrinsic rate constant, $\mathrm{mol} \mathrm{m}^{-2} \mathrm{~s}^{-1}$ & $1.22 \times 10^{-4}$ \\
\hline$\eta$ & $\mathrm{pH}$ power law coefficient & 0.34 \\
\hline $\mathrm{E}_{\mathrm{a}}$ & Activation energy, $\mathrm{kJ} \mathrm{mol}^{-1}$ & 60.2 \\
\hline $\mathrm{K}_{\mathrm{g}}$ & Log equilibrium constant & 0.966 \\
\hline
\end{tabular}

Based on experimental observations, soluble technetium is assumed to be evenly distributed in a 2-cm zone in the cast refractory next to the sides of the glass. The initial amount of technetium in the cast refractory is assumed to be $0.3 \%$ of the total amount in the waste package (McGrail et al. 2003). 


\subsubsection{Grout Materials}

The grout is assumed to be composed of tobermorite-14A (representing CSH gel), ettringite, portlandite, and sodium hydroxide (Table 12) (Bacon and McGrail 2003; Criscenti et al. 1996). Rate constants are uncertain. In this analysis, the relative degradation rates of the various components investigated previously (Krupka and Serne 1998) have been assumed.

Table 12. Grout Reactions

\begin{tabular}{||l|c|c|l||}
\hline \multicolumn{1}{|c|}{ Reaction } & $\begin{array}{c}\text { Rate Constant, } \\
\text { mol m }\end{array}$ & $\begin{array}{c}\text { Log } \mathbf{~} \\
\mathbf{s}^{-1} \\
(\mathbf{1 5} \mathbf{C})\end{array}$ & \multicolumn{1}{|c||}{ Source } \\
\hline Sodium hydroxide $+\mathrm{H}^{+}=\mathrm{Na}^{+}+\mathrm{H}_{2} \mathrm{O}$ & $1 \times 10^{-11}$ & 21.5 & (Wolery 1992) \\
\hline Ettringite $+\mathrm{H}^{+}=\mathrm{SO}_{4}^{2-}+\mathrm{Ca}^{2+}+\mathrm{H}_{2} \mathrm{O}+\mathrm{AlO}_{2}^{-}$ & $1 \times 10^{-13}$ & 16.9 & (Sarkar et al. 1982) \\
\hline Portlandite $+\mathrm{H}^{+}=\mathrm{Ca}^{2+}+\mathrm{H}_{2} \mathrm{O}$ & $1 \times 10^{-11}$ & 23.3 & (Robie et al. 1978) \\
\hline Tobermorite-14A $+\mathrm{H}^{+}=\mathrm{Ca}^{2+}+\mathrm{SiO}_{2}(\mathrm{aq})+\mathrm{H}_{2} \mathrm{O}$ & $1 \times 10^{-13}$ & 67.2 & (Sarkar et al. 1982) \\
\hline $\mathrm{AgI}=\mathrm{Ag}^{+}+\mathrm{I}^{-}$ & $1 \times 10^{-9}$ & -16.0 & (Pierce et al. 2004a) \\
\hline $\mathrm{Ba}\left(\mathrm{IO}_{3}\right)_{2}=\mathrm{Ba}^{2+}+2 \mathrm{IO}_{3}^{-}$ & $1 \times 10^{-9}$ & -8.4 & (Lide 2004) \\
\hline $\mathrm{BaI}_{2}=\mathrm{Ba}^{2+}+2 \mathrm{I}^{-}$ & $1 \times 10^{-9}$ & 11.3 & (Chase et al. 1985) \\
\hline
\end{tabular}

\subsubsection{Secondary Phases}

Pierce et al. (2004a, 2004b) describe the methods used to develop a solubility product for the key secondary phases identified from laboratory testing and from simulations with the EQ3/6 code. For convenience, the $\log \mathrm{K}$ they derived for each secondary phase given in Table 8 is reproduced in Table 13. For the secondary phases, where a log K was not available or could not be estimated, the reaction was not included in the STORM simulations.

\subsubsection{Initial and Boundary Conditions}

For each specified gas species concentration, the partial pressure of gaseous species is needed. The gas partial pressure for $\mathrm{CO}_{2}$ and $\mathrm{O}_{2}$ were fixed at atmospheric values of $3 \times 10^{-4}$ and $2.1 \times 10^{-1}$ atm, respectively.

For each specified aqueous species, the specified total concentration and the stoichiometric coefficient of each aqueous species are needed. Aqueous species concentrations at the upper boundary, and for initial conditions, were specified as a part of the near-field geochemistry data package (Krupka et al. 2004) and are given in Table 14. Total aqueous species concentrations were specified at the upper boundary, and a no-diffusion condition was imposed across the lower boundary. The contaminant flux across the lower boundary was therefore limited to advection:

$$
f=c \rho_{w} v
$$


Table 13. Secondary Phase Reaction Network

\begin{tabular}{|c|c|}
\hline Reaction & $\begin{array}{l}\log K \\
\left(15^{\circ} \mathrm{C}\right)\end{array}$ \\
\hline Analcime $\rightleftharpoons 0.96 \mathrm{AlO}_{2}^{-}+0.96 \mathrm{Na}^{+}+2.04 \mathrm{SiO}_{2}(\mathrm{aq})$ & -16.47 \\
\hline Anatase $+2 \mathrm{H}_{2} \mathrm{O} \rightleftharpoons \mathrm{Ti}(\mathrm{OH})_{4}(\mathrm{aq})$ & -6.56 \\
\hline Baddeleyite $+2 \mathrm{H}_{2} \mathrm{O} \rightleftharpoons \mathrm{Zr}(\mathrm{OH})_{4}(\mathrm{aq})$ & -6.79 \\
\hline Calcite $+\mathrm{H}^{+} \rightleftharpoons \mathrm{Ca}^{2+}+\mathrm{HCO}_{3}^{-}$ & 2.00 \\
\hline Chalcedony $\rightleftharpoons \mathrm{SiO}_{2}(\mathrm{aq})$ & -3.94 \\
\hline Clinochlore-14A $+8 \mathrm{H}^{+} \rightleftharpoons 3 \mathrm{SiO}_{2}(\mathrm{aq})+5 \mathrm{Mg}^{2+}+8 \mathrm{H}_{2} \mathrm{O}+2 \mathrm{AlO}_{2}^{-}$ & 22.93 \\
\hline $\mathrm{Fe}(\mathrm{OH})_{3}(\mathrm{am})+\mathrm{H}_{2} \mathrm{O} \rightleftharpoons \mathrm{Fe}(\mathrm{OH})_{3}(\mathrm{aq})$ & -11.09 \\
\hline Gibbsite $\rightleftharpoons \mathrm{AlO}_{2}^{-}+\mathrm{H}_{2} \mathrm{O}$ & -13.10 \\
\hline Gypsum $\rightleftharpoons \mathrm{Ca}^{2+}+\mathrm{SO}_{4}^{2-}+\mathrm{H}_{2} \mathrm{O}$ & -4.49 \\
\hline $\mathrm{La}(\mathrm{OH})_{3}(\mathrm{am})+3 \mathrm{H}^{+} \rightleftharpoons 3 \mathrm{H}_{2} \mathrm{O}+\mathrm{La}^{3+}$ & 20.29 \\
\hline $\mathrm{PuO}_{2}+\mathrm{HCO}_{3}{ }^{-}+0.5 \mathrm{O}_{2}(\mathrm{aq}) \rightleftharpoons \mathrm{PuO}_{2}\left(\mathrm{CO}_{3}\right)_{3}{ }^{4-}+\mathrm{H}_{2} \mathrm{O}+\mathrm{H}^{+}$ & -15.92 \\
\hline Nontronite- $\mathrm{Na}+2 \mathrm{H}_{2} \mathrm{O} \rightleftharpoons 0.330 \mathrm{AlO}_{2}^{-}+2 \mathrm{Fe}(\mathrm{OH})_{3}(\mathrm{aq})+0.330 \mathrm{Na}^{+}+3.67 \mathrm{SiO}_{2}(\mathrm{aq})$ & -43.33 \\
\hline Sepiolite $+8 \mathrm{H}^{+} \rightleftharpoons 4 \mathrm{Mg}^{2+}+6 \mathrm{SiO}_{2}(\mathrm{aq})+11 \mathrm{H}_{2} \mathrm{O}$ & 31.29 \\
\hline $\mathrm{SiO}_{2}(\mathrm{am}) \rightleftharpoons \mathrm{SiO}_{2}(\mathrm{aq})$ & -2.85 \\
\hline Soddyite $\rightleftharpoons 2 \mathrm{UO}_{2}(\mathrm{OH})_{2}(\mathrm{aq})+\mathrm{SiO}_{2}(\mathrm{aq})$ & -20.24 \\
\hline Theophrasite $+2 \mathrm{H}^{+} \rightleftharpoons 2 \mathrm{H}_{2} \mathrm{O}+\mathrm{Ni}^{2+}$ & 13.33 \\
\hline Weeksite $+2 \mathrm{H}^{+} \rightleftharpoons 2 \mathrm{~K}^{+}+2 \mathrm{UO}_{2}(\mathrm{OH})_{2}(\mathrm{aq})+6 \mathrm{SiO}_{2}(\mathrm{aq})+3 \mathrm{H}_{2} \mathrm{O}$ & -5.25 \\
\hline $\mathrm{Zn}(\mathrm{OH})_{2}($ gamma $)+2 \mathrm{H}^{+} \rightleftharpoons 2 \mathrm{H}_{2} \mathrm{O}+\mathrm{Zn}^{2+}$ & 11.88 \\
\hline
\end{tabular}

Table 14. Initial Aqueous Concentrations Used in Simulations

\begin{tabular}{|c|c|}
\hline Species & $\begin{array}{c}\text { Initial Concentration } \\
\left(\mathrm{mol} \mathrm{kg}^{-1}\right)\end{array}$ \\
\hline $\mathrm{AlO}_{2}^{-}$ & $10^{-6}$ \\
\hline $\mathrm{B}(\mathrm{OH})_{3}(\mathrm{aq})$ & $10^{-10}$ \\
\hline $\mathrm{Ca}^{2+}$ & $10^{-7}$ \\
\hline Cr (total) & $10^{-10}$ \\
\hline $\mathrm{Fe}(\mathrm{OH})_{3}(\mathrm{aq})$ & $10^{-10}$ \\
\hline $\mathrm{H}_{2} \mathrm{O}$ & 1 \\
\hline $\mathrm{H}^{+}$ & $10^{-7}$ \\
\hline $\mathrm{IO}_{3}^{-}$ & $10^{-10}$ \\
\hline $\mathrm{K}^{+}$ & $10^{-6}$ \\
\hline $\mathrm{La}^{3+}$ & $10^{-10}$ \\
\hline $\mathrm{Mg}^{2+}$ & $10^{-10}$ \\
\hline $\mathrm{Na}^{+}$ & $10^{-6}$ \\
\hline $\mathrm{Ni}^{2+}$ & $10^{-10}$ \\
\hline $\mathrm{SeO}_{4}{ }^{2-}$ & $10^{-10}$ \\
\hline Si (total) & $10^{-5}$ \\
\hline $\mathrm{TcO}_{4}^{-}$ & $10^{-10}$ \\
\hline $\mathrm{Ti}(\mathrm{OH})_{4}(\mathrm{aq})$ & $10^{-10}$ \\
\hline $\mathrm{U}$ (total) & $10^{-10}$ \\
\hline $\mathrm{Zn}^{2+}$ & $10^{-10}$ \\
\hline $\mathrm{Zr}(\mathrm{OH})_{4}(\mathrm{aq})$ & $10^{-10}$ \\
\hline
\end{tabular}


where

$C=$ concentration $\left(\mathrm{mol} \mathrm{kg}^{-1}\right)$

$\rho_{w}=$ density of water $\left(\mathrm{kg} \mathrm{m}^{-3}\right)$

$v=$ specific discharge $\left(\mathrm{m} \mathrm{s}^{-1}\right)$.

\subsection{Model Output}

The normalized flux to the vadose zone is calculated by summing the flux at each node across the bottom boundary of the model and normalizing the total flux according to the amount of each radionuclide in all the waste packages at the start of the simulation. The normalized flux across the lower boundary, $F$, in units of $\mathrm{Myr}^{-1}$, was calculated using

$$
F=\frac{\sum_{i=1}^{N} f_{i} \Delta x_{i} \Delta y_{i}}{I_{j}} \zeta
$$

where

$f_{i}=$ flux across the bottom of an individual grid block (mole $\left.\mathrm{m}^{-2} \mathrm{~s}^{-1}\right)$

$\Delta x_{i} \Delta y_{i}=$ cross-sectional area of an individual grid block $\left(\mathrm{m}^{2}\right)$

$$
\zeta=\frac{3.1558 \times 10^{13} \mathrm{~s}}{\mathrm{Myr}}
$$

$I_{j} \quad=$ inventory of $j^{\text {th }}$ radionuclide in the simulated waste packages (mol), where

$$
I_{j}=V_{w p}\left(1-\theta_{T}\right) \rho_{G} \gamma_{j}
$$

where

$V_{w p} \quad=$ volume of the waste packages $\left(\mathrm{m}^{3}\right)$

$\theta_{T}=$ total porosity of the material representing the waste packages $\left(\mathrm{m}^{3} \mathrm{~m}^{-3}\right)$

$\rho_{G} \quad=$ molar density of the material representing the waste packages $\left(\mathrm{mol} \mathrm{m}^{-3}\right)$

$\gamma_{j}=$ mole fraction of $j$ th radionuclide in the material representing the waste packages $\left(\mathrm{mol} \mathrm{mol}{ }^{-1}\right)$.

The volume of the four simulated waste packages, $V_{w p}$, was $11.2 \mathrm{~m}^{3}$ for the WTP glass simulations, $13.7 \mathrm{~m}^{3}$ for the bulk vitrification glass simulations, and $11.9 \mathrm{~m}^{3}$ for the grout simulations. The crosssectional area of each grid block was $0.02 \mathrm{~m}^{2}$.

The units of $\mathrm{Myr}^{-1}$ (pronounced "per million years") are equivalent to units of "ppm/yr" that were used in previous performance assessments (Mann et al. 2001, 1998). The term ppm was used to express the fraction of radionuclide released from the waste packages per year in "per millionth," similar to the commonly used percent term. However, the unit ppm, when used in environmental science for expressing levels of pollutants in water, has the specific meaning of mg/liter (mg of contaminant per liter of water). 
Using ppm to mean "per millionth,” while correct, may be confusing in this context and has been replaced with units of $\mathrm{Myr}^{-1}$.

The radionuclide concentrations, for instance Tc, are also normalized by the inventory,

$$
\mathrm{Tc}_{\text {normalized }}=\frac{\mathrm{Tc}}{I_{\mathrm{Tc}}}
$$




\subsection{Results}

Nineteen simulations were run to test the sensitivity of model calculations to various assumptions, including waste form material and recharge rate (Table 15). Several waste form materials were simulated, including three WTP glasses (LAWA44, LAWB45, and LAWC22), grout, and two bulk vitrification glasses (six-tank composite and S-109). LAWA44 glass subject to a recharge rate of $0.9 \mathrm{~mm} \mathrm{yr}^{-1}$ is used as the base case. The discussion of the selection of recharge rates provided in Section 2 describes hydraulic boundary conditions. A discussion of the results of each simulation is presented in the following sections, and a summary of the results is presented in Table 15.

\subsection{WTP Glasses}

Three WTP glasses were simulated, LAWA44, LAWB45 and LAWC22 (Table 5). The LAW streams are divided into three classifications or compositional envelopes (Envelopes A, B, and C). In general, the chemical composition of each envelope is characteristic of one of the three major chemical separation processes used to extract plutonium: REDOX (Envelope A), and later plutonium and uranium (bismuth phosphate [Envelope B]) and PUREX (Envelope C) from irradiated fuels at Hanford.

Table 15. Results of Waste Form Sensitivity Cases

\begin{tabular}{|c|c|c|c|c|}
\hline Material & $\begin{array}{c}\text { Recharge Rate, } \\
\text { mm yr }^{-1}\end{array}$ & Radionuclide & \begin{tabular}{|c|} 
Maximum Normalized \\
Radionuclide Flux, Myr $^{-1}$ \\
\end{tabular} & $\begin{array}{c}\text { Why Result is Different from } \\
\text { Base Case }\end{array}$ \\
\hline LAWA44 & 0.9 & Тc-99 & \begin{tabular}{|c|}
$9.1 \times 10^{-2}$ \\
\end{tabular} & Base Case \\
\hline LAWABP1 & 0.9 & Тс-99 & $3.6 \times 10^{-2}$ & $\begin{array}{l}\text { Rate law parameters from } 2001 \\
\text { ILAW PA }\end{array}$ \\
\hline LAWABP1 & 0.9 & Тс-99 & $6.7 \times 10^{-3}$ & $\begin{array}{l}\text { Rate law parameters from } 2005 \\
\text { IDF DP }\end{array}$ \\
\hline LAWA44 & 0.5 & Тc-99 & $9.3 \times 10^{-2}$ & $\begin{array}{l}\text { Not significantly different due to } \\
\text { competing effects of equilibrium } \\
\text { with silica and sodium ion- } \\
\text { exchange }\end{array}$ \\
\hline LAWA44 & 0.1 & Tc-99 & $1.2 \times 10^{-1}$ & $\begin{array}{l}\text { Not significantly different due to } \\
\text { competing effects of equilibrium } \\
\text { with silica and sodium ion- } \\
\text { exchange }\end{array}$ \\
\hline LAWA44 & 4.2 & Тс-99 & $1.0 \times 10^{-1}$ & $\begin{array}{l}\text { Not significantly different due to } \\
\text { competing effects of equilibrium } \\
\text { with silica and sodium ion- } \\
\text { exchange }\end{array}$ \\
\hline LAWB45 & 0.9 & Тc-99 & $9.3 \times 10^{-3}$ & $\begin{array}{l}\text { Ion exchange rate lower than } \\
\text { LAWA44 }\end{array}$ \\
\hline LAWC22 & 0.9 & Тс-99 & $1.2 \times 10^{-1}$ & $\begin{array}{l}\text { Ion exchange rate higher than } \\
\text { LAWA44 }\end{array}$ \\
\hline $\begin{array}{l}\text { LAWA44/ } \\
\text { LAWB45 } \\
\end{array}$ & 0.9 & Tc-99 & $\begin{array}{l}\text { LAWA44 }=7.3 \times 10^{-2} \\
\text { LAWB45 }=2.8 \times 10^{-2}\end{array}$ & $\begin{array}{l}\text { Ion exchange rate of LAWB45 } \\
\text { lower (lower } \mathrm{pH} \text { ) than LAWA44 }\end{array}$ \\
\hline $\begin{array}{l}\text { LAWA44/ } \\
\text { LAWB45 } \\
\end{array}$ & 0.9 & Tc-99 & $\begin{array}{l}\text { LAWA44 }=8.7 \times 10^{-2} \\
\text { LAWC22 }=1.0 \times 10^{-1}\end{array}$ & Not significantly different \\
\hline
\end{tabular}

Table 15 (contd) 


\begin{tabular}{|c|c|c|c|c|}
\hline Material & $\begin{array}{c}\text { Recharge Rate, } \\
{\text { mm } \mathrm{yr}^{-1}}^{-1}\end{array}$ & Radionuclide & $\begin{array}{c}\text { Maximum Normalized } \\
\text { Radionuclide Flux, } \text { Myr }^{-1}\end{array}$ & $\begin{array}{c}\text { Why Result is Different from } \\
\text { Base Case }\end{array}$ \\
\hline BV 6-tank & 0.9 & Тс-99 & $\begin{array}{l}\text { Glass }+ \text { salt }=4.4 \times 10^{0} \\
\text { Glass only }=1.0 \times 10^{-1}\end{array}$ & $\begin{array}{l}\text { Glass release is similar to base } \\
\text { case; salt release varies linearly } \\
\text { with recharge rate }\end{array}$ \\
\hline BV 6-tank & 0.5 & Тс-99 & $\begin{array}{l}\text { Glass }+ \text { salt }=2.4 \times 10^{0} \\
\text { Glass-only }=1.1 \times 10^{-1}\end{array}$ & $\begin{array}{l}\text { Glass release is similar to base } \\
\text { case; salt release varies linearly } \\
\text { with recharge rate }\end{array}$ \\
\hline BV S-109 & 0.9 & Tc-99 & $\begin{aligned} \text { Glass }+ \text { salt } & =4.4 \times 10^{0} \\
\text { Glass-only } & =1.7 \times 10^{-1}\end{aligned}$ & $\begin{array}{l}\text { Higher pseudo-equilibrium } \\
\text { coefficient and ion exchange rate } \\
\text { than BV 6-tank }\end{array}$ \\
\hline BV, salt-only & 0.1 & Tc-99 & $3.1 \times 10^{-1}$ & $\begin{array}{l}\text { Salt release varies linearly with } \\
\text { recharge rate }\end{array}$ \\
\hline BV, salt-only & 4.2 & Тс-99 & $1.7 \times 10^{+1}$ & $\begin{array}{l}\text { Salt release varies linearly with } \\
\text { recharge rate }\end{array}$ \\
\hline Grout, AgI & 0.9 & I-129 & $4.6 \times 10^{-6}$ & $\begin{array}{l}\text { I-129 release from grout depends } \\
\text { on solubility of AgI, log Ksp = - } \\
16.0\end{array}$ \\
\hline Grout, $\mathrm{BaI}_{2}$ & 0.9 & I-129 & $2.4 \times 10^{+2}$ & $\begin{array}{l}\text { I-129 release from grout depends } \\
\text { on solubility of } \mathrm{BaI}_{2}, \log \mathrm{Ksp}=- \\
8.4\end{array}$ \\
\hline $\begin{array}{l}\text { Grout, } \\
\mathrm{Ba}\left(\mathrm{IO}_{3}\right)_{2}\end{array}$ & 0.9 & I-129 & $9.1 \times 10^{-1}$ & $\begin{array}{l}\text { I-129 release from grout depends } \\
\text { on solubility of } \mathrm{Ba}\left(\mathrm{IO}_{3}\right)_{2}, \log \mathrm{Ksp} \\
=11.3\end{array}$ \\
\hline LAWA44 & 0.9 & Tc-99 & Same as base case & Extends base case to water table \\
\hline
\end{tabular}

\subsubsection{LAWA44}

The maximum normalized flux of technetium to the vadose zone for LAWA44 glass at a recharge rate of $0.9 \mathrm{~mm} \mathrm{yr}^{-1}$ is $0.09 \mathrm{Myr}^{-1}$ at 3,000 $\mathrm{yr}$ (Figure 4). The normalized technetium flux to the vadose zone is proportional to the $\mathrm{TcO}_{4}^{-}$concentration at the lower boundary and the water flux rate (which remains constant because flow is assumed to be steady state). The water flow field within and surrounding the WTP glass waste packages at a recharge rate of $0.9 \mathrm{~mm} / \mathrm{yr}$ is shown in Figure 5 . Because the porosity of the WTP glass is lower than that of the surrounding backfill, and because the pores drain easily, water flows mostly around the outside of each waste package, while a relatively small amount flows through the glass fractures. The glass dissolution rate increases steadily with time as the $\mathrm{pH}$ (Figure 6) in the pore water inside the glass fractures increases. After 1300 years, the glass dissolution rate (Figure 7) reaches a quasi-stationary state value as the silica concentrations in the pore water within the glass fractures increase to a value approaching the apparent equilibrium coefficient for the glass (Table 12). The $\mathrm{TcO}_{4}^{-}$ concentration at the lower boundary is very small at early times and increases gradually with time as the glass dissolves and the technetium is transported by advection and diffusion through water in fractures of the glass, out into the pores of the backfill, and downward through the Hanford sand (Figure 8). 


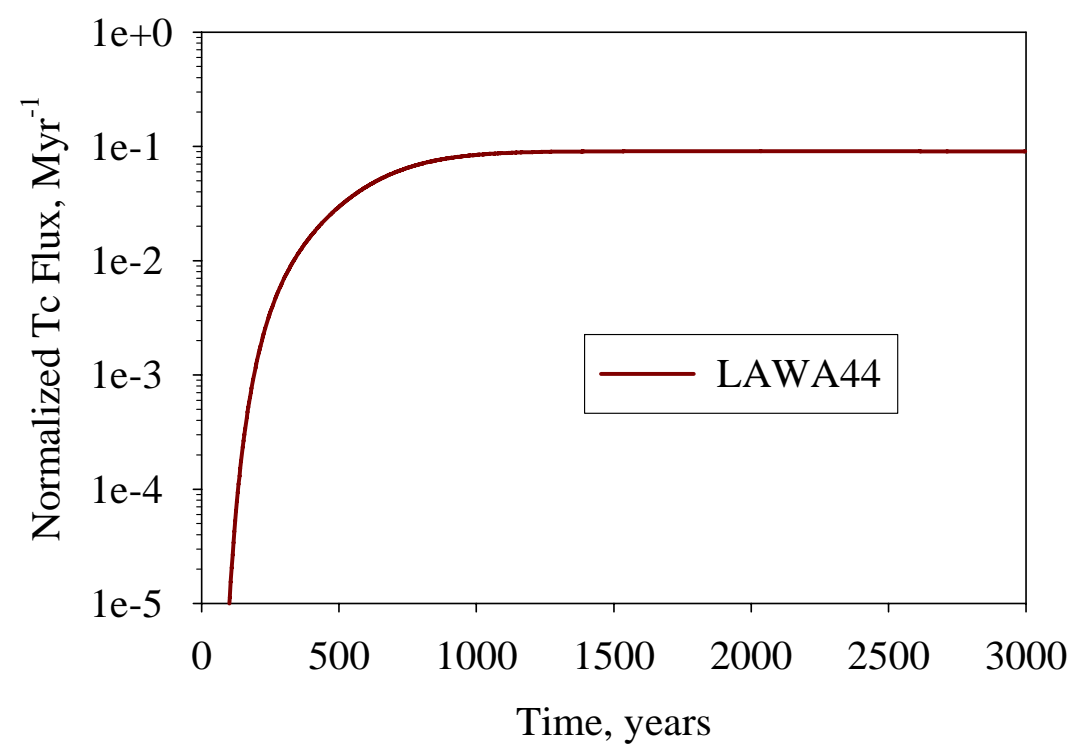

Figure 4. Technetium Flux to Vadose Zone, Normalized by Total Amount of Technetium Originally in WTP Glass Waste Packages at Recharge Rate of $0.9 \mathrm{~mm} \mathrm{yr}^{-1}$

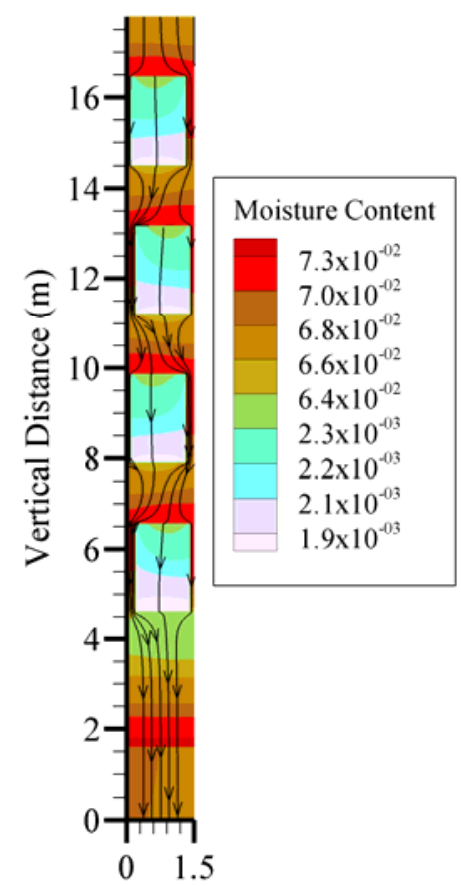

Horizontal Distance (m)

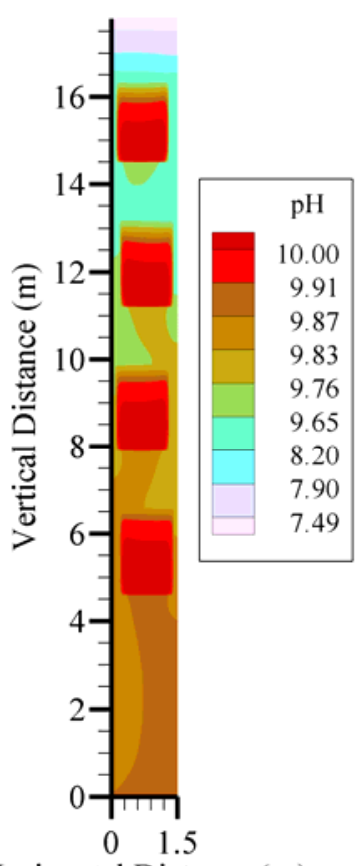

Horizontal Distance (m)
Figure 5. Steady-State Moisture Content for $0.9 \mathrm{~mm} \mathrm{yr}^{-1}$ Recharge Rate WTP Glass Waste Form Release Simulations
Figure 6. Maximum $\mathrm{pH}$ for LAWA44 Waste Form Release Simulations at $0.9 \mathrm{~mm} \mathrm{yr}^{-1}$ Recharge Rate 


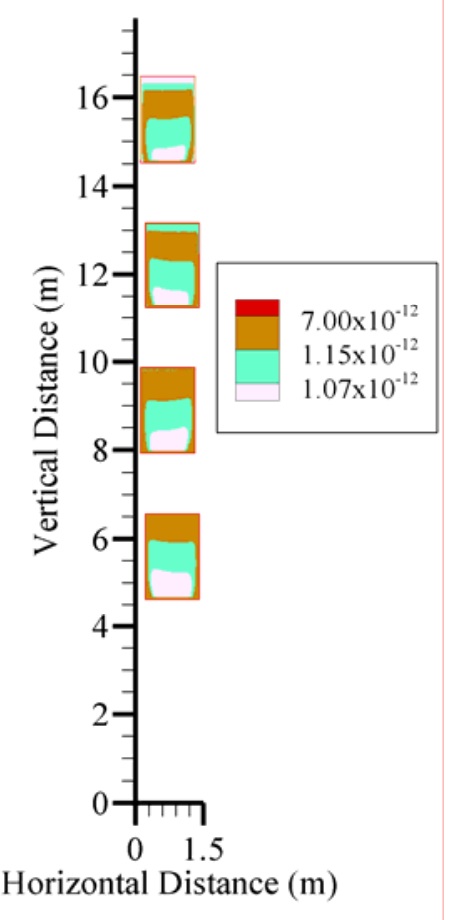

Figure 7. Maximum Glass Dissolution Rate $\left(\mathrm{mol} \mathrm{m} \mathrm{s}^{-1}\right)$ for LAWA44 Waste Form Release Simulations at a $0.9 \mathrm{~mm} \mathrm{yr}^{-1}$ Recharge Rate

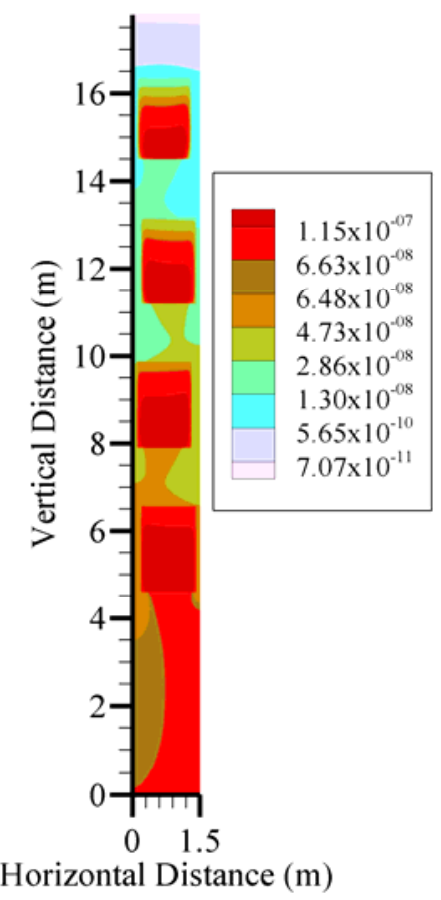

Figure 8. Maximum Normalized Technetium Concentrations $\left(\mathrm{kg}^{-1}\right)$ for LAWA44 Waste Form Release Simulations at a $0.9 \mathrm{~mm} \mathrm{yr}^{-1}$ Recharge Rate

\subsubsection{LAWA44 Versus LAWABP1}

The maximum normalized flux of technetium to the vadose zone for LAWA44 glass at a recharge rate of $0.9 \mathrm{~mm} \mathrm{yr}^{-1}, 0.09 \mathrm{Myr}^{-1}$ at 3,000 $\mathrm{yr}$, is 10 times lower than the predicted value for the base case of the 2001 ILAW PA (Bacon and McGrail 2001), which was $0.93 \mathrm{Myr}^{-1}$. The base case for the 2001 ILAW PA differed from the current base case in that it was a 1-D simulation of LAWABP1 glass at a higher water recharge rate of $4.2 \mathrm{~mm} \mathrm{yr}^{-1}$.

For a better comparison to the previous PA, a simulation of LAWABP1 glass with composition, aqueous species, and secondary minerals as described in the 2001 ILAW PA (Bacon and McGrail 2001) was developed using the hydraulic properties and water recharge rate described for LAWA44 in this report. The maximum normalized flux of technetium to the vadose zone for LAWABP1 glass using rate law parameters from the 2001 ILAW PA at a recharge rate of $0.9 \mathrm{~mm} \mathrm{yr}^{-1}$ is $0.036 \mathrm{Myr}^{-1}$ at 3,000 yr (Figure 9). This is similar to the technetium flux predicted by a 2-D simulation for the 2001 ILAW PA.

For a more up-to-date comparison of LAWA44 and LAWBP1, another simulation was run using the latest experimentally derived rate law parameters for LAWABP1 given in the waste form release data package for the 2005 IDF PA (Pierce et al. 2004a) and shown in Table 12. The maximum normalized flux of technetium to the vadose zone for LAWABP1 glass using rate law parameters from the 2005 IDF waste form release DP at a recharge rate of $0.9 \mathrm{~mm} \mathrm{yr}^{-1}$ is considerably lower, $0.067 \mathrm{Myr}^{-1}$ at 3,000 $\mathrm{yr}$ (Figure 9). 


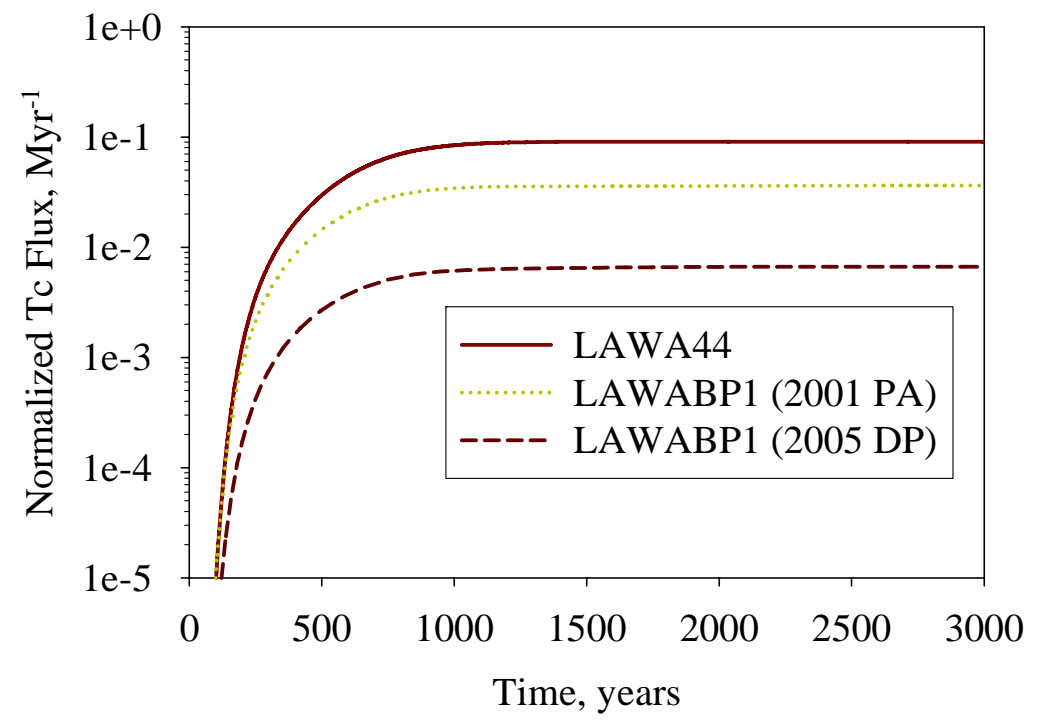

Figure 9. Technetium Flux to the Vadose Zone Normalized by Total Amount of Technetium Originally in WTP Glass Waste Packages for LAWA44 and LAWABP1 Glasses Using Rate Law Parameters from 2001 PA and 2005 Data Package (DP)

\subsubsection{Effect of Recharge Rate on LAWA44}

Simulations of LAWA44 glass weathering at recharge rates of 4.2, 0.9, 0.5 and $0.1 \mathrm{~mm} \mathrm{yr}^{-1}$ were run to examine the effect of recharge rate on technetium flux to the vadose zone. Rather than decreasing linearly with recharge rate, technetium flux to the vadose zone does not vary greatly with recharge rate (Figure 10, Table 16).

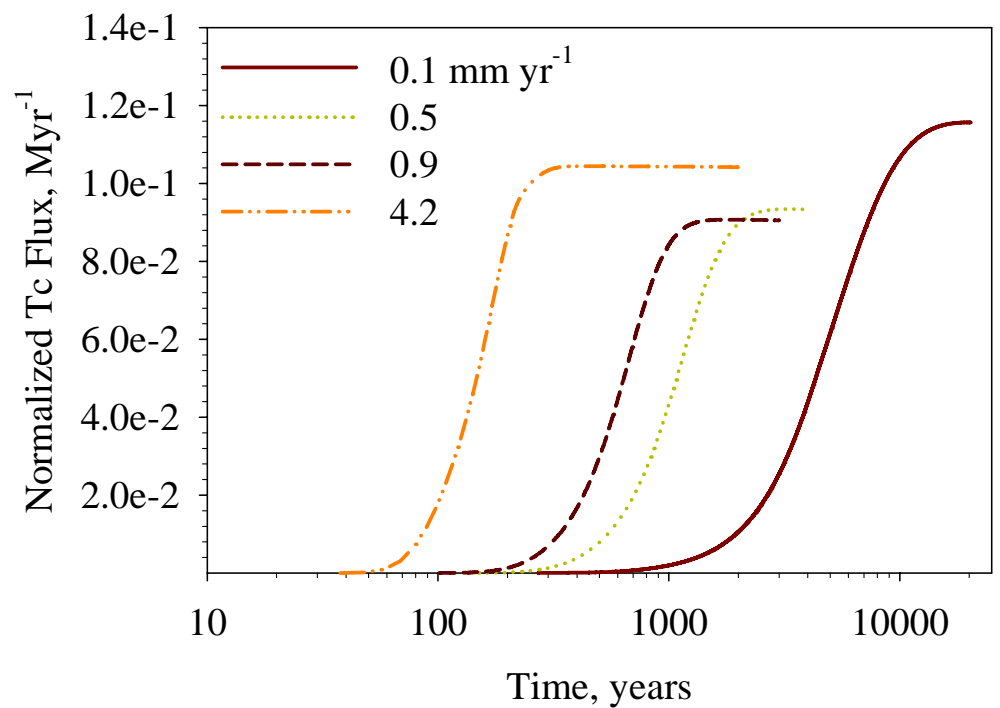

Figure 10. Technetium Flux to the Vadose Zone Normalized by Total Amount of Technetium Originally in WTP Glass Waste Packages at Various Recharge Rates 
Table 16. Maximum Normalized Technetium Flux to the Vadose Zone for Various Recharge Rates

\begin{tabular}{||c|c||}
\hline $\begin{array}{c}\text { Recharge Rate, } \\
\text { mm } \mathbf{~ r ~}^{-\mathbf{1}}\end{array}$ & $\begin{array}{c}\text { Maximum Normalized } \\
\text { Tc-99 Flux, } \mathbf{M y r}^{-1}\end{array}$ \\
\hline 0.1 & $1.2 \times 10^{-1}$ \\
\hline 0.5 & $9.3 \times 10^{-2}$ \\
\hline 0.9 & $9.1 \times 10^{-2}$ \\
\hline 4.2 & $1.0 \times 10^{-1}$ \\
\hline
\end{tabular}

The glass dissolution rate is controlled by aqueous silica and $\mathrm{pH}$. As the recharge rate decreases, the $\mathrm{SiO}_{2}$ (aq) concentration remains fixed at $10^{-3.26} \mathrm{~mol} \mathrm{~kg}^{-1}$, which is the measured pseudo-equilibrium coefficient for LAWA44 glass. Chalcedony is precipitating, but not at a high enough rate to control aqueous silica. However, as the recharge rate decreases, the $\mathrm{pH}$ increases, because the sodium-ion exchange rate remains constant, and the water content decreases. Here the technetium flux does not decrease linearly with recharge rate, but instead remains relatively constant as these competing effects cancel each other.

\subsubsection{LAWB45 and LAWC22}

Simulations of two other WTP glass formulations LAWB45 and LAWC22 (Table 5) were performed using the same hydraulic conditions and waste package configuration as for LAWA44 (Figure 1) at a recharge rate of $0.9 \mathrm{~mm} \mathrm{yr}^{-1}$. The normalized release of Tc-99 from LAWB45 glass, $0.009 \mathrm{Myr}^{-1}$, is an order of magnitude lower than for LAWA44 (Figure 11). Ion exchange is not significant for LAWB45, as shown in Table 12, resulting in a lower $\mathrm{pH}$ (Figure 12) and hence lower glass dissolution rate.

The normalized release of Tc-99 from LAWC22 glass, $0.11 \mathrm{Myr}^{-1}$, is $22 \%$ higher than that for LAWA44 (Figure 11). The ion exchange rate for LAWC22 is twice that for LAWA44 (Table 12) resulting in a higher $\mathrm{pH}$ (Figure 13) and hence higher glass dissolution rate.

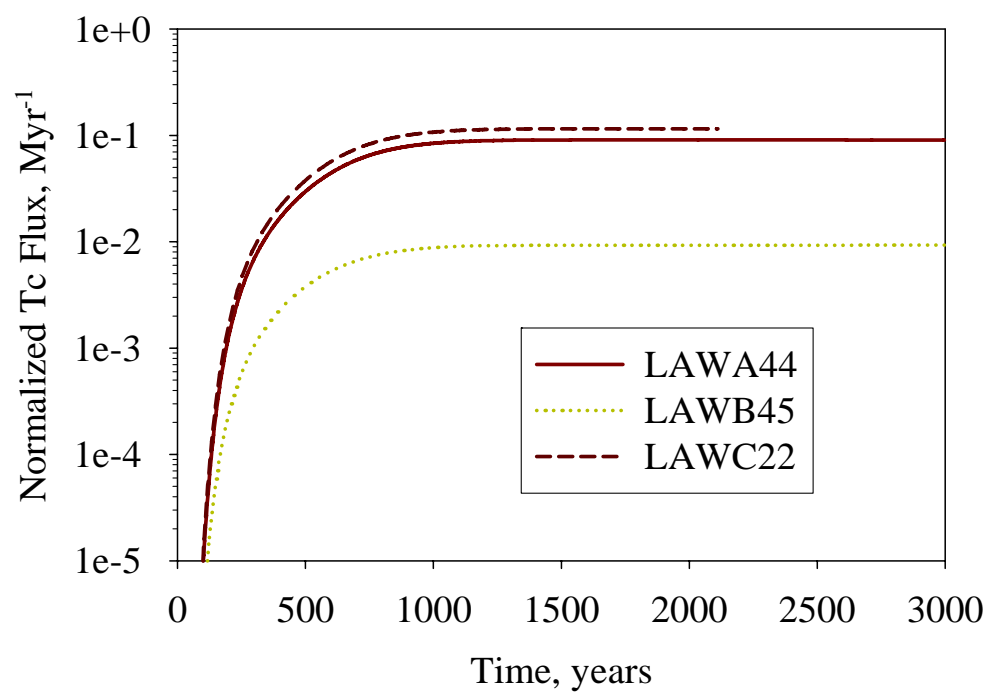

Figure 11. Technetium Flux to the Vadose Zone at a Recharge Rate of $0.9 \mathrm{~mm} \mathrm{yr}^{-1}$ for Various WTP Glasses 


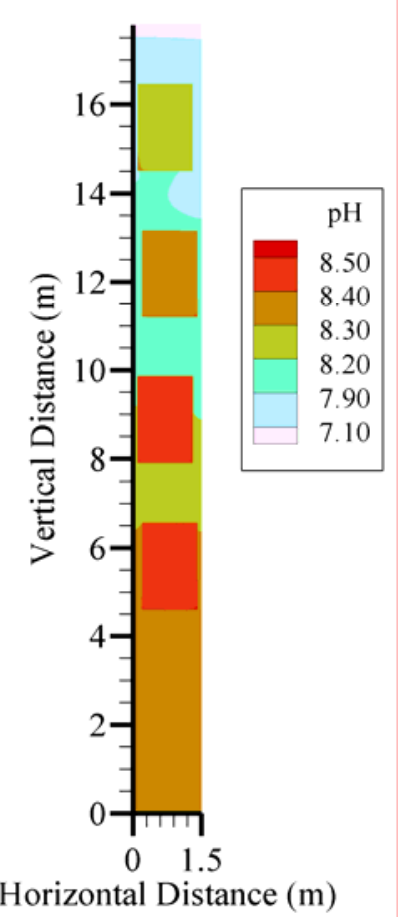

Figure 12. Maximum $\mathrm{pH}$ for LAWB45 Waste Form Release Simulations at $0.9 \mathrm{~mm} \mathrm{yr}^{-1}$ Recharge Rate

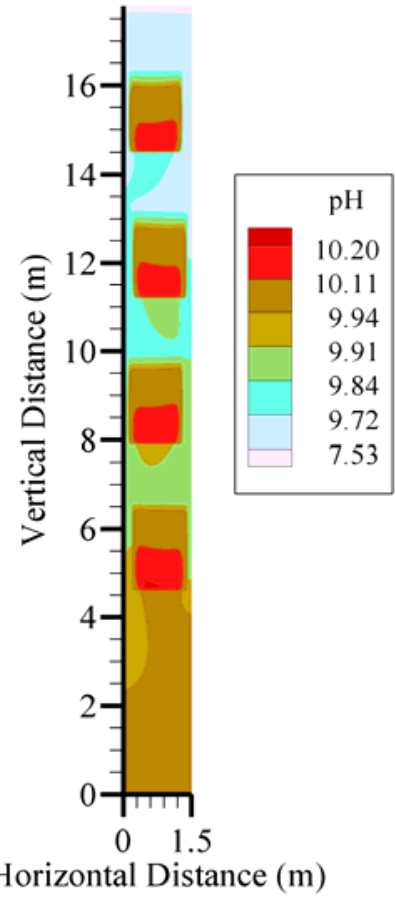

Figure 13. Maximum $\mathrm{pH}$ for LAWC22 Waste Form Release Simulations at $0.9 \mathrm{~mm} \mathrm{yr}^{-1}$ Recharge Rate

The normalized release of Tc-99 from LAWA44 glass interleaved in a stack with LAWB45, $0.073 \mathrm{Myr}^{-1}$, is $19 \%$ lower than LAWA44 alone (Figure 14). Conversely, the normalized release of Tc-99 from LAWB45 glass interleaved in a stack with LAWA44 glass, $0.028 \mathrm{Myr}^{-1}$, is three times higher than LAWB45 alone. The ion exchange for LAWA44 results in a significantly higher $\mathrm{pH}$ within and

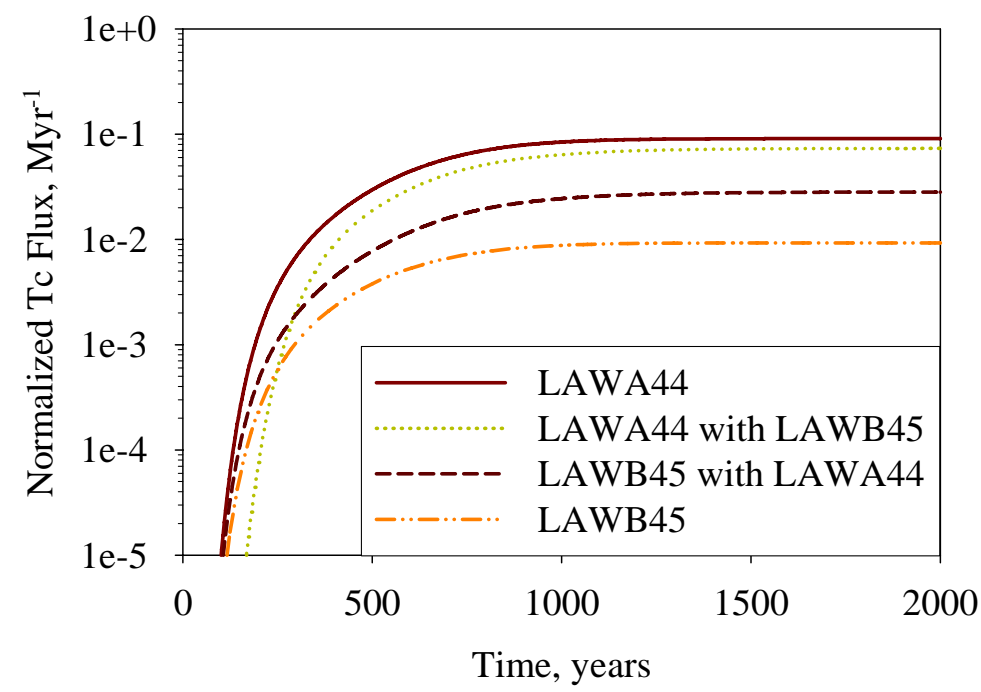

Figure 14. Technetium Flux to the Vadose Zone at Recharge Rate of $0.9 \mathrm{~mm} \mathrm{yr}^{-1}$ for LAWA44 and LAWB45 Glasses Alone or Combined 
downgradient from that glass (Figure 15). Hence, LAWB45 glass has a significantly higher release rate when exposed to the higher $\mathrm{pH}$ flowing from LAWA44 packages. The $\mathrm{pH}$ increases with each successive layer of waste packages. Because there are only two layers of LAWA44, the LAWA44 glass has a lower release rate than the base case with four layers of waste packages with the same composition.

A simulation of interleaved LAWA44 and LAWC22 glass was performed. The normalized release of Tc-99 from LAWA44 glass interleaved in a stack with LAWC22, $0.087 \mathrm{Myr}^{-1}$, is only 3\% lower than that of LAWA44 alone (Figure 16). The normalized release of Tc-99 from LAWC22 glass interleaved in a stack with LAWA44 glass, $0.10 \mathrm{Myr}^{-1}$, is $13 \%$ lower than that of LAWC22 alone. The lower ion exchange for LAWA44 relative to LAWC22 results in a lower $\mathrm{pH}$ within and downgradient from that glass (Figure 17). Hence, LAWC22 glass has a lower release rate when exposed to the lower $\mathrm{pH}$ emitting from LAWA44 packages. Because the $\mathrm{pH}$ increases downgradient with each successive layer of waste packages, and in this case only the upper first and third layers consist of LAWA44, the LAWA44 glass has a lower release rate than the base case, where the second and fourth layers also consist of that type of waste package.

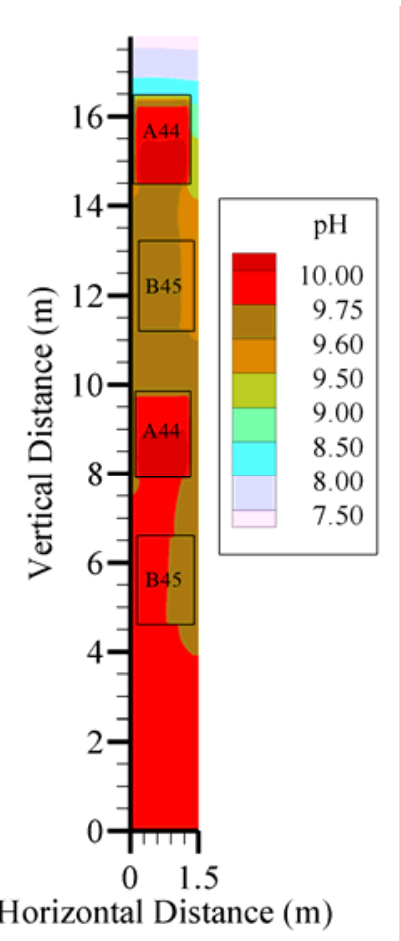

Figure 15. Maximum $\mathrm{pH}$ for LAWA44 with LAWAB45 Waste Form Release Simulations at a $0.9 \mathrm{~mm} \mathrm{yr}^{-1}$ Recharge Rate 


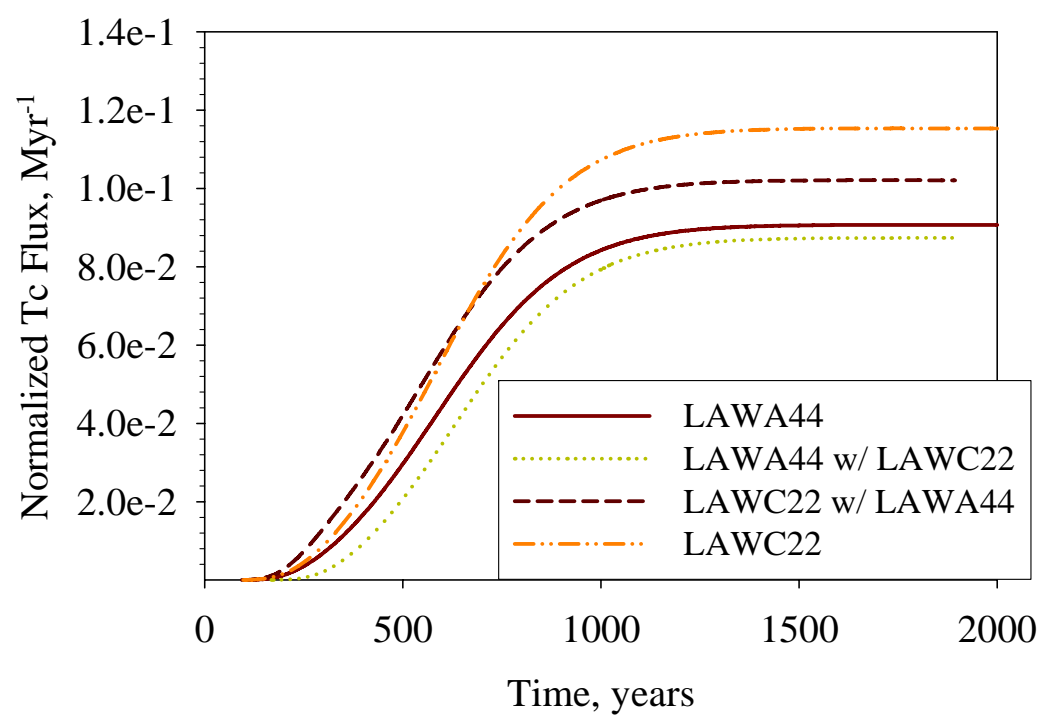

Figure 16. Technetium Flux to the Vadose Zone at a Recharge Rate of $0.9 \mathrm{~mm} \mathrm{yr}^{-1}$ for LAWA44 and LAWC22 Glasses, Alone or Combined

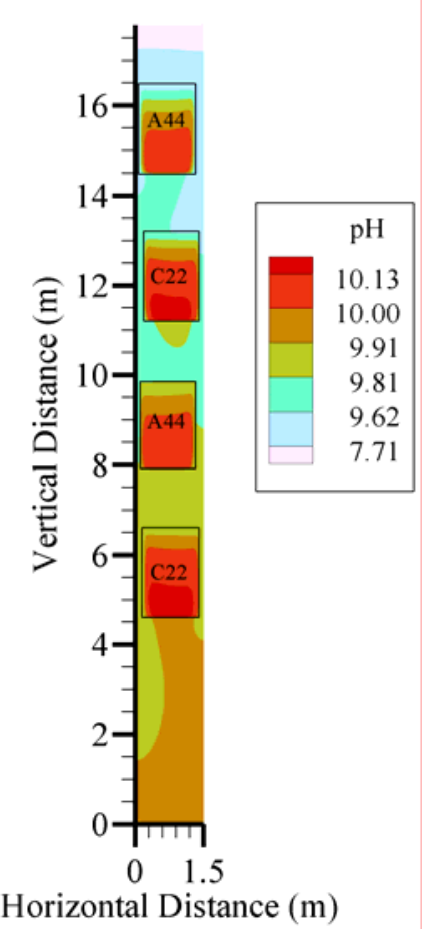

Figure 17. Maximum $\mathrm{pH}$ for LAWA44 with LAWAC22 Waste Form Release Simulations at a $0.9 \mathrm{~mm} \mathrm{yr}^{-1}$ Recharge Rate 


\subsection{Bulk Vitrification}

A comparison of the six-tank composite and S-109 technetium fluxes shows good agreement at times before 2000 years (Figure 18). A comparison of the normalized Tc-99 release rate for bulk vitrification and WTP glass indicates that, at times before 2000 years, nearly all of the Tc-99 crossing the lower model boundary has come from the soluble $\mathrm{KTcO}_{4}$ (s) salt. At times later than 2000 years, all Tc-99 flux is due to waste glass dissolution, which has reached a quasi-stationary dissolution rate. The quasi-stationary state glass dissolution rate for the six-tank composite glass, $0.1 \mathrm{Myr}^{-1}$, is slightly higher than that for LAWA44 glass, whereas the dissolution rate for S-109 glass, $0.17 \mathrm{Myr}^{-1}$, is $70 \%$ higher. The higher release rate for the S-109 glass is attributed to the higher pseudo-equilibrium coefficient and ion exchange rate (Table 12).

A simulation of the six-tank composite glass at a recharge rate of $0.5 \mathrm{~mm} \mathrm{yr}^{-1}$ is also shown in comparison to the same glass at a recharge rate at $0.9 \mathrm{~mm} \mathrm{yr}^{-1}$ (Figure 19). The peak for a recharge rate of $0.5 \mathrm{~mm} \mathrm{yr}^{-1}$ is lower and more spread out than that for a recharge rate of $0.9 \mathrm{~mm} \mathrm{yr}^{-1}$ due to a longer travel time through the vadose zone, which allows more mixing by diffusion and dispersion. The quasistationary state technetium flux to the vadose zone after several thousand years is due to release from the glass only, after the soluble technetium salt has been flushed out.

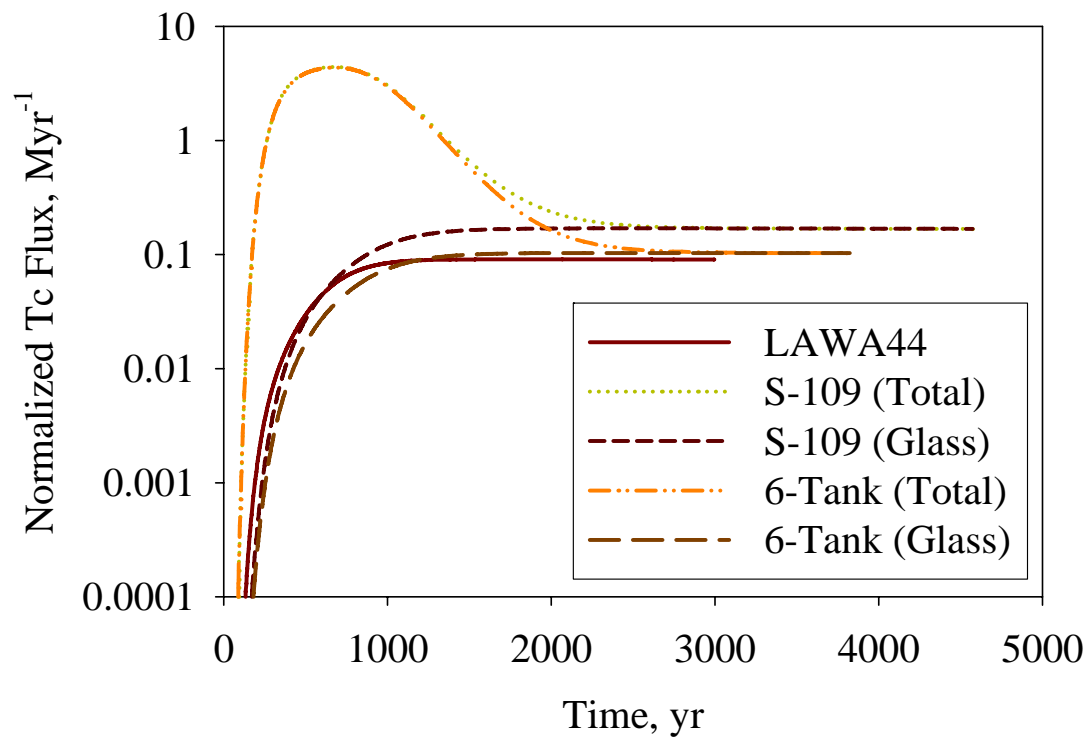

Figure 18. Comparison of Technetium Flux to the Vadose Zone Normalized by Total Amount of Technetium Originally in Bulk Vitrification Waste Packages for Different Waste Glass Formulations at a Recharge Rate of $0.9 \mathrm{~mm} \mathrm{yr}^{-1}$ 


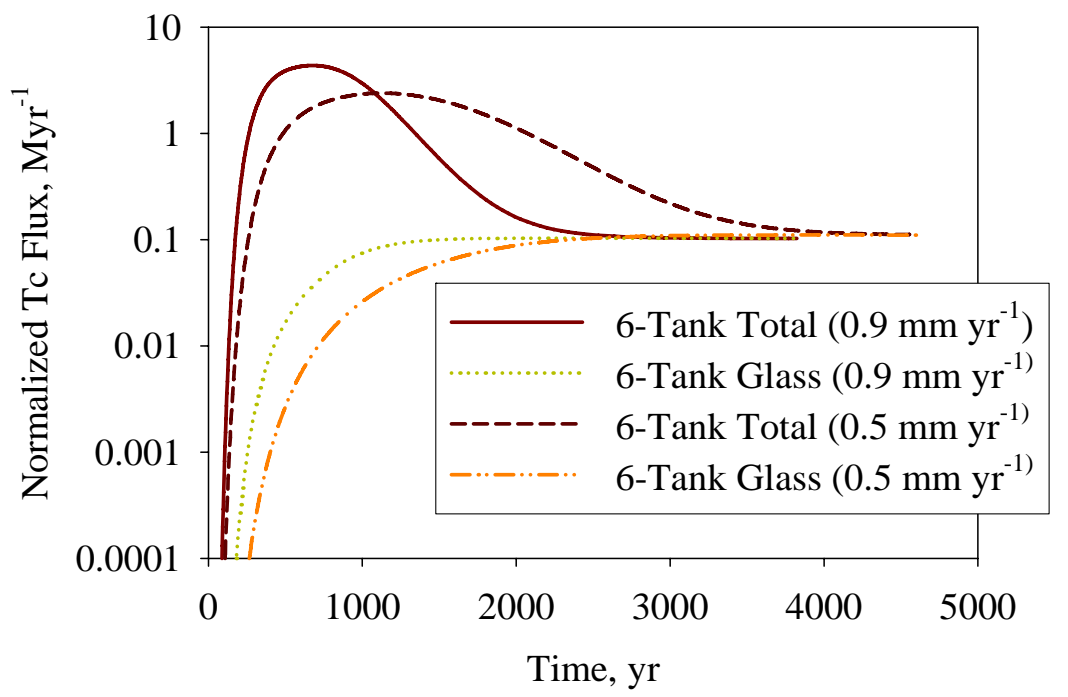

Figure 19. Comparison of Technetium Flux to the Vadose Zone Normalized by Total Amount of Technetium Originally in Bulk Vitrification Waste Packages for Six-Tank Composite Glass at Various Recharge Rates

There were not enough computing resources available to complete full reactive transport simulations of both bulk vitrification glasses at recharge rates of 4.2 and $0.1 \mathrm{~mm} \mathrm{yr}^{-1}$. The LAWA44 glass dissolution rate was insensitive to recharge rate, and the same is probable for the bulk vitrification glasses. However, the soluble technetium salt flux is likely to be sensitive to recharge rate because its release from the waste form and transport from the waste package is controlled by advection and diffusion. Thus, solute transport simulations of the release of the soluble technetium salt at recharge rates of 4.2 and $0.1 \mathrm{~mm} \mathrm{yr}^{-1}$ were run with STOMP (Figure 20) and compared with salt release from reactive transport simulations (Table 12). The peak technetium release increases linearly with increasing recharge rate, whereas the time to reach the peak concentration decreases logarithmically with increasing recharge rate.

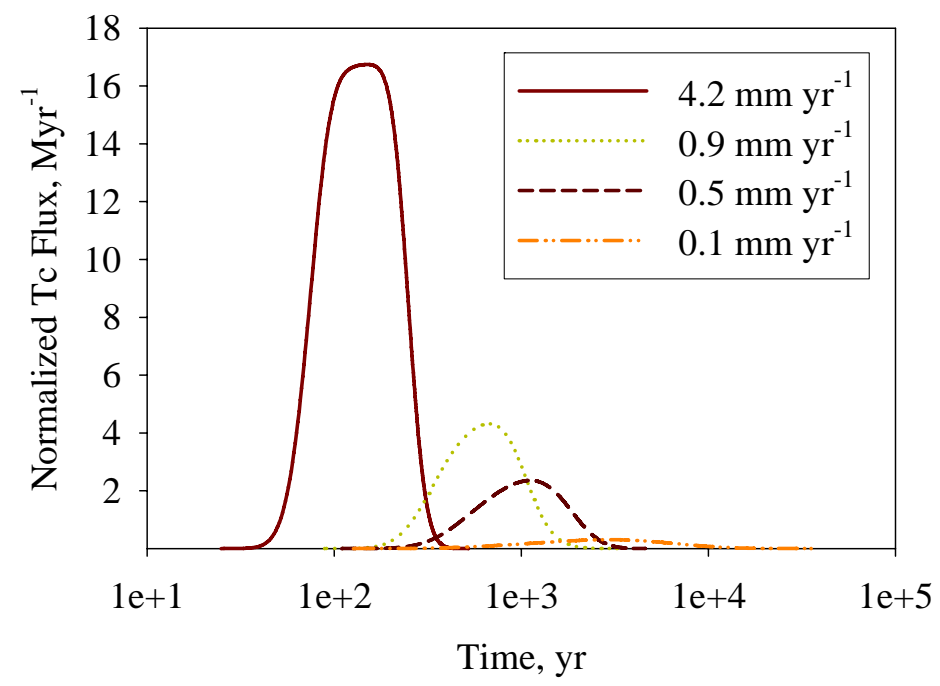

Figure 20. Comparison of Normalized Flux of Technetium Salt to the Vadose Zone for Different Water Recharge Rates 


\subsection{Grouted Secondary Waste}

Iodine release simulations were performed for grouted secondary waste. These radioactive iodine releases were limited by the solubility of various iodine salts. Three iodine-containing salts were considered: silver iodide, barium iodate, and barium iodide (Table 11). The effective diffusion coefficient for $\mathrm{I}^{-}$and $\mathrm{IO}_{3}{ }^{-}$were assumed to be $2.6 \times 10^{-9} \mathrm{~cm}^{2} / \mathrm{s}$ (Pierce et al. 2004a). The log $\mathrm{K}$ for barium iodide is so high that the iodine release rate $\left(2.4 \times 10^{2} \mathrm{Myr}^{-1}\right)$ is essentially limited only by diffusion (Figure 21). The normalized iodine release rate from grout containing barium iodate $\left(9.1 \times 10^{-1} \mathrm{Myr}^{-1}\right)$ is two orders of magnitude lower, whereas the iodine release from grout containing silver iodide $\left(4.6 \times 10^{-6} \mathrm{Myr}^{-1}\right)$ is more than seven orders of magnitude lower.

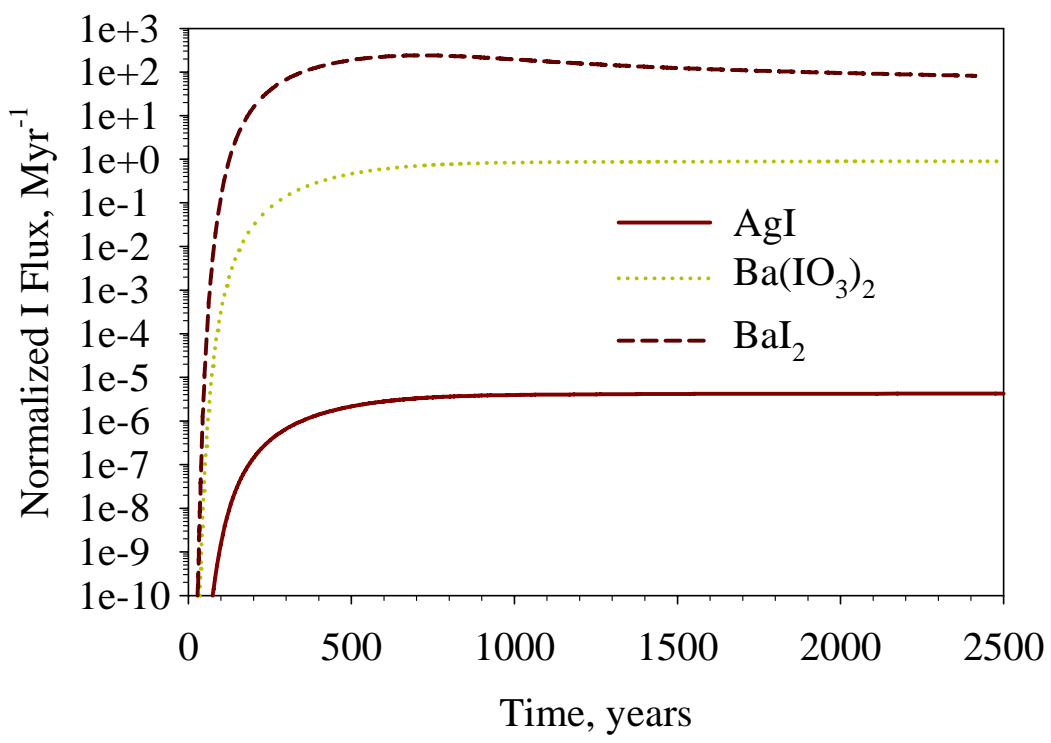

Figure 21. Iodine Flux to the Vadose Zone at a Recharge Rate of $0.9 \mathrm{~mm} \mathrm{yr}^{-1}$ for Various Iodine Salts in Grout Waste Forms

\subsection{Far-Field Simulation}

A far-field simulation was performed to estimate the distribution of $\mathrm{pH}$ with time in the deep vadose zone. This information is needed to estimate changes in the uranium solid/aqueous distribution coefficient (Kd) with time, which is $\mathrm{pH}$-dependent. The far field extends from the bottom of the waste disposal facilities to the groundwater. The material beneath the waste facilities is Hanford sand, which is projected to extend to a depth of $65 \mathrm{~m}$ below surface level. Beneath the Hanford sand is the Hanford gravel, which extends to the projected post-Hanford water table at $103 \mathrm{~m}$ below ground surface. Each material is represented as a homogeneous medium for the respective sediment types. Hydraulic properties for the Hanford sand and Hanford gravel were given in Table 3. A 1-D simulation was performed to estimate the pore water chemistry in the deep vadose zone beneath the IDF. The initial conditions were the same as the near-field simulations (Table 14). The upper boundary concentrations for the far-field simulation were fixed at the maximum concentrations encountered at the bottom boundary of the base case near-field simulation (Table 17). At a recharge rate of $0.9 \mathrm{~mm} \mathrm{yr}^{-1}, 8000$ years was required for elevated $\mathrm{pH}$ to propagate through the deep vadose zone to the water table (Figure 22). 
Table 17. Upper Boundary Aqueous Species Concentrations Used in Far-Field Simulation

\begin{tabular}{||l|c||}
\hline \multicolumn{1}{|c|}{ Species } & $\begin{array}{c}\text { Initial Concentration } \\
\text { ( mol kg-1 }\end{array}$ \\
\hline $\mathrm{AlO}_{2}{ }^{-1}$ & $2.7 \times 10^{-8}$ \\
\hline $\mathrm{B}(\mathrm{OH})_{3}(\mathrm{aq})$ & $4.1 \times 10^{-4}$ \\
\hline $\mathrm{Ca}^{2+}$ & $7.1 \times 10^{-7}$ \\
\hline $\mathrm{CrO}_{4}{ }^{2-}$ & $2.4 \times 10^{-6}$ \\
\hline $\mathrm{Fe}(\mathrm{OH})_{3}(\mathrm{aq})$ & $1.2 \times 10^{-6}$ \\
\hline $\mathrm{H}_{2} \mathrm{O}$ & $9.9 \times 10^{-1}$ \\
\hline $\mathrm{H}^{+}$ & $1.3 \times 10^{-10}$ \\
\hline $\mathrm{K}^{+}$ & $1.4 \times 10^{-4}$ \\
\hline $\mathrm{Mg}^{2+}$ & $4.9 \times 10^{-6}$ \\
\hline $\mathrm{Na}^{+}$ & $2.0 \times 10^{-1}$ \\
\hline $\mathrm{Si}_{(\mathrm{total})}$ & $6.0 \times 10^{-5}$ \\
\hline $\mathrm{TcO}_{4}^{-}$ & $5.4 \times 10^{-6}$ \\
\hline $\mathrm{Ti}(\mathrm{OH})_{4}(\mathrm{aq})$ & $2.2 \times 10^{-7}$ \\
\hline $\mathrm{Zn}{ }^{2+}$ & $2.6 \times 10^{-8}$ \\
\hline $\mathrm{Zr}(\mathrm{OH})_{4}(\mathrm{aq})$ & $1.3 \times 10^{-7}$ \\
\hline
\end{tabular}

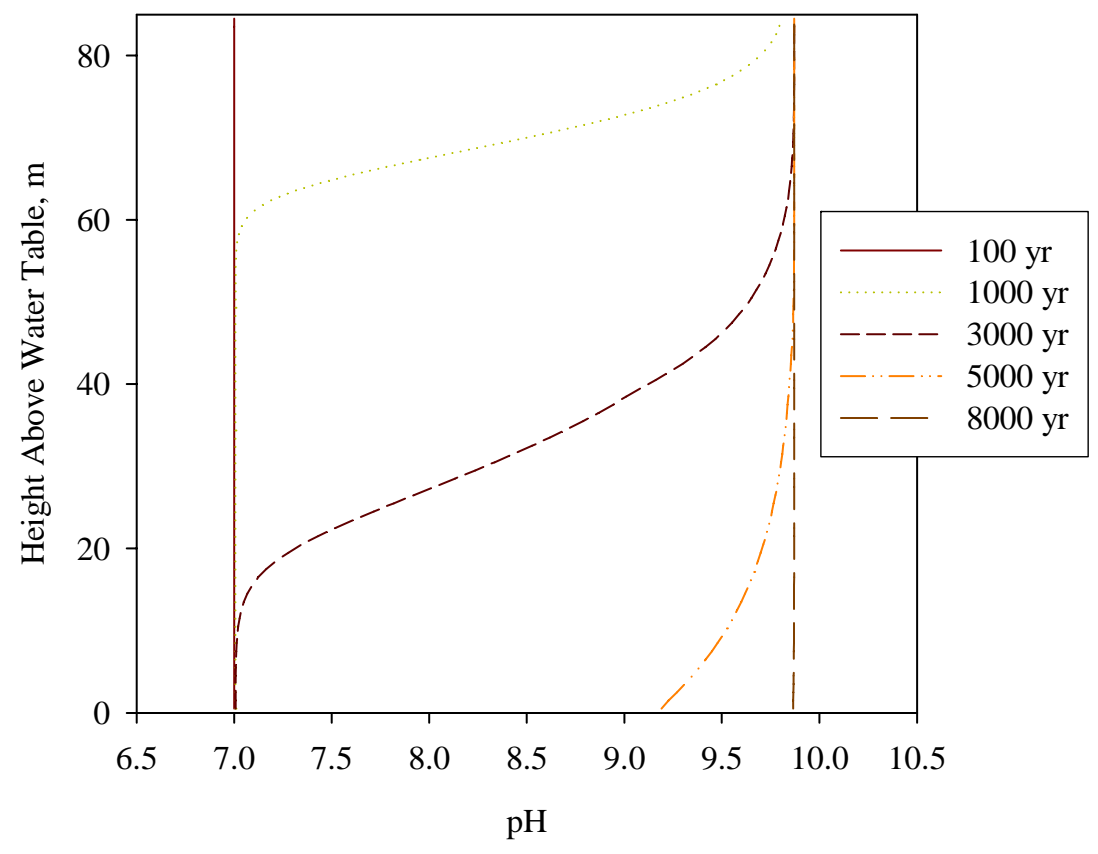

Figure 22. Distribution of $\mathrm{pH}$ with Time in the Deep Vadose Zone 


\subsection{Conclusion}

The primary difference between the waste form release simulations for the 2001 ILAW PA and the simulations described in this document for the IDF PA is the number of different materials considered. Whereas the ILAW PA considered only LAWABP1 glass, the current IDF PA describes radionuclide release from three WTP glasses (LAWA44, LAWB45 and LAWC22), two bulk vitrification glasses (sixtank composite and S-109), and three grout waste forms containing AgI, $\mathrm{BaI}_{2}$ and $\mathrm{Ba}\left(\mathrm{IO}_{3}\right)_{2}$. All WTP and bulk vitrification glasses perform similarly. However, the radionuclide release from the salt in the cast refractory surrounding the bulk vitrification waste packages is 2 to 170 times higher than the glass release rate, depending on the water recharge rate. Iodine-129 release from grouted waste forms is highly sensitive to the solubility of the iodine compound contained in the grout. The normalized iodine release

rate from grout containing barium iodate $\left(9.1 \times 10^{-1} \mathrm{Myr}^{-1}\right)$ is a factor of 10 higher than the normalized release rate would be if the iodine were contained in LAWA44 glass. 


\subsection{References}

Bacon DH and BP McGrail. 2001. Waste Form Release Calculations for the 2001 Immobilized LowActivity Waste Performance Assessment. PNNL-13369, Pacific Northwest National Laboratory, Richland, Washington.

Bacon DH and BP McGrail. 2003. "Waste Form Release Calculations for Performance Assessment of the Hanford Immobilized Low-Activity Waste Disposal Facility Using a Parallel, Coupled Unsaturated Flow and Reactive Transport Simulator." In 2002 Materials Research Society Fall Meeting Proceedings, Symposium II, Scientific Basis for Nuclear Waste Management XXVI, RJ Finch and DB Bullen, Materials Research Society, Warrendale, Pennsylvania.

Bacon DH, BP McGrail, VL Freedman, G Ventura, P Risoluti, and KM Krupka. 2002. "Performance Assessment of Low-Level Waste Disposal Facilities Using Coupled Unsaturated Flow and Reactive Transport Simulators." In 2001 Materials Research Society Fall Meeting Proceedings, Symposium JJ, Scientific Basis for Nuclear Waste Management XXV, BP McGrail and GA Cragnolino, Materials Research Society, Warrendale, Pennsylvania.

Bacon DH, MD White, and BP McGrail. 2004. Subsurface Transport Over Reactive Multiphases (STORM): A Parallel, Coupled, Nonisothermal Multiphase Flow, Reactive Transport, and Porous Medium Alteration Simulator, Version 3.0, User's Guide. PNNL-14783, Pacific Northwest National Laboratory, Richland, Washington.

Chase MW, CA Davies, JR Downey, DJ Frurip, RA McDonald, and AN Syverud. 1985. "Janaf thermochemical tables 3rd ed.” J. Phys. Chem. Ref. Data, 14, Supplement 1.

Criscenti LJ, RJ Serne, KM Krupka, and MI Wood. 1996. Predictive Calculations to Assess the LongTerm Effect of Cementitious Materials on the $\mathrm{pH}$ and Solubility of uranium (VI) in a Shallow and Disposal Environment. PNNL-11182, Pacific Northwest National Laboratory, Richland, Washington.

Daveler SA and TJ Wolery. 1992. EQPT, A Data File Preprocessor for the EQ3/6 Software Package: User's Guide and Related Documentation (Version 7.0). UCRL-MA-110662 PT II, Lawrence Livermore National Laboratory, Livermore, California.

Farnsworth RK, MKW Chan, and SC Slate. 1985. "The Effect of Radial Temperature Gradients on Glass Fracture in Simulated High-Level Waste Canisters.” Mat. Res. Soc. Symp. Proc., 44:831-838.

Fayer MJ and JE Szecsody. 2004. Recharge Data Package for the 2005 Integrated Disposal Facility Performance Assessment. PNNL-14744, Pacific Northwest National Laboratory, Richland, Washington.

Hall C and WD Hoff. 2002. Water transport in brick, stone, and concrete. Spon Press, New York.

Khaleel R. 2004. Far-Field Hydrology Data Package for the Integrated Disposal Facility Performance Assessment. RPP-20621, Rev. 0, CH2M Hill Hanford Group, Richland, Washington.

Krupka KM and RJ Serne. 1998. Effects on Radionuclide Concentrations by Cement/Ground-Water Interactions in Support of Performance Assessment of Low-Level Radioactive Waste Disposal Facilities. PNNL-11408, NUREG/CR-6377, Pacific Northwest National Laboratory, Richland, Washington.

Krupka KM, RJ Serne, and DI Kaplan. 2004. Geochemical Data Package for the 2005 Hanford Integrated Disposal Facility Performance Assessment. PNNL-13037 Rev. 2, Pacific Northwest National Laboratory, Richland, Washington.

Lide DR. 2004. CRC Handbook of Chemistry and Physics, 85th Edition. CRC Press, Boca Raton, Florida.

Mann FM, KC Burgard, WR Root, RJP II, SH Finfrock, R Khaleel, DH Bacon, EJ Freeman, BP McGrail, SK Wurstner, and PE Lamont. 2001. Hanford Immobilized Low-Activity Waste Performance Assessment: 2001 Version. DOE/ORP-2000-24 Rev. 0, Department of Energy, Office of River Protection, Richland, Washington.

Mann FM, RJ Puigh, II, CR Eiholzer, Y Chen, NW Kline, AH Lu, BP McGrail, PD Rittmann, GF Williamson, NR Brown, and PE LaMont. 1998. Hanford Immobilized Low Activity Tank Waste 
Performance Assessment. DOE/RL-97-69 Rev. B, Project Hanford Management Contractor, Richland, Washington.

McGrail BP and DH Bacon. 1998. Selection of a Computer Code for Hanford Low-Level Waste Engineered-System Performance Assessment. PNNL-10830 Rev. 1, Pacific Northwest National Laboratory, Richland, Washington.

McGrail BP, DH Bacon, JP Icenhower, FM Mann, RJ Puigh, HT Schaef, and SV Mattigod. 2001. “Nearfield performance assessment for a low-activity waste glass disposal system: laboratory testing to modeling results.” Journal of Nuclear Materials, 298:95-111.

McGrail BP, DH Bacon, RJ Serne, and EM Pierce. 2003. A Strategy to Assess Performance of Selected Low-Activity Waste Forms in an Integrated Disposal Facility. PNNL-14362, Pacific Northwest National Laboratory, Richland, Washington.

Meyer PD, KP Saripalli, and VL Freedman. 2004. Near-Field Hydrology Data Package for the Integrated Disposal Facility 2005 Performance Assessment. PNNL-14700, Pacific Northwest National Laboratory, Richland, Washington.

Mualem Y. 1976. A Catalogue of the Hydraulic Properties of Unsaturated Soils. Research Project 442, Technion, Israel Institute of Technology, Haifa, Israel.

Peters RD and SC Slate. 1981. "Fracturing of Simulated High-Level Waste Canisters.” Nuc. Eng. Design, 67:425-445.

Pierce EM, BP McGrail, EA Rodriguez, HT Schaef, K Saripalli, RJ Serne, PF Martin, SR Baum, KN Geiszler, LR Reed, and WJ Shaw. 2004a. Waste Form Release Data Package for the 2005 Integrated Disposal Facility Performance Assessment. PNNL-14805, Pacific Northwest National Laboratory, Richland, Washington.

Pierce EM, BP McGrail, EA Rodriguez, DM Wellman, LR Reed, DH Bacon, HT Schaef, and SR Baum. 2004b. Laboratory Testing of Bulk Vitrified Low-Activity Waste Form to Support the 2005 Integrated Disposal Facility Performance Assessment. PNNL-15126, Pacific Northwest National Laboratory, Richland, Washington.

Puigh RJ. 2004. Facility Data for the Hanford Integrated Disposal Facility Performance Assessment. RPP-20691, Rev. 0, Fluor Government Group, Richland, Washington.

Robie RA, BS Hemingway, and JR Fisher. 1978. Thermodynamic Properties of Minerals and Related Substances at 298.15K and 1 Bar Pressure and at Higher Temperatures. U.S. Geological Survey Bulletin 1452, U.S. Government Printing Office, Washington, D.C.

Sarkar AK, MW Barnes, and DM Roy. 1982. Longevity of borehole and shaft sealing materials: thermodynamic properties of cements and related phases applied to repository sealing. ONWI Tech. Rep. ONWI-201, Office of Nuclear Waste Isolation, Washington, D. C.

Serne RJ, JL Conca, VL LeGore, KJ Cantrell, CW Lindenmeier, JA Campbell, JE Amonette, and MI Wood. 1993. Solid-Waste Leach Characteristics and Contaminant-Sediment Interactions. Volume 1: Batch Leach and Adsorption Tests and Sediment Characterization. PNL-8889 Vol. 1, Pacific Northwest Laboratory, Richland, Washington.

Wolery TJ. 1992. EQ3NR, A Computer Program for Geochemical Aqueous Speciation-Solubility Calculations: Theoretical Manual, User's Guide, and Related Documentation (Version 7.0). UCRL-MA-110662 PT III, Lawrence Livermore National Laboratory, Livermore, California.

Wolery TJ and SA Daveler. 1992. EQ6, A Computer Program for Reaction Path Modeling of Aqueous Geochemical Systems: Theoretical Manual, User's Guide, and Related Documentation (Version 7.0). UCRL-MA-110662 PT IV, Lawrence Livermore National Laboratory, Livermore, California. 


\section{Distribution}

No. of

Copies

OFFSITE

Argonne National Laboratory

Building 205

9700 South Cass Avenue

Argonne, IL 60439-4837

ATTN: WL Ebert

Lawrence Berkeley National Laboratory

Earth Sciences Division

University of California

Berkeley, CA 94720

ATTN: K Pruess

2 Lawrence Livermore National Laboratory

University of California

7000 East Avenue

Livermore, CA 94550-9234

ATTN: TJ Wolery, Mailcode L-219

WE Glassley, Mailcode L-202

University of Central Florida

322 Engineering Building I

Orlando, FL 32816-2450

ATTN: G-T Yeh

4 Yucca Mountain Site Characterization

Program

TRW Environmental Safety System

1180 Town Center Drive

Mail Stop 423

Las Vegas, NV 89134

ATTN: R Andrews

E Bartlett Mann

J Lee

Y Chen
No. of

Copies

ONSITE

6 CH2M HILL Hanford Group

MC Connelly E6-35

JG Field H6-62

FM Mann $\quad$ E6-35

B McMahon E6-45

G Parsons H6-19

R Raymond H6-22

3 U.S. Department of Energy/ORP

RW Lober H6-60

PE Lamont H6-60

RM Yasek H6-60

2 Fluor Daniel Hanford, Inc.

BH Ford $\quad$ E6-35

MI Wood H8-44

2 Fluor Federal Services, Inc.

R Khaleel B4-43

RJ Puigh B4-43

33 Pacific Northwest National Laboratory

DH Bacon (5) K9-33

LM Bagaasen K6-28

SQ Bennett K6-50

MP Bergeron K9-36

RW Bryce K6-75

WJ Deutsch K6-81

Y Fang K9-36 
No. of

Copies

MJ Fayer K9-33

VL Freedman K9-36

MD Freshley K9-33

CT Kincaid K9-33

KM Krupka K6-81

PE Long K9-33

BP McGrail (5) K6-81

WE Nichols K9-33

MC Richmond K9-33

ML Rockhold K9-36

KP Saripalli $\quad$ K6-81

TD Scheibe K9-36

RJ Serne P7-22

MD White K9-36

SB Yabusaki K9-36

F Zhang K9-33

Information Release (2) P8-55 